\title{
Dynamics and Consequences of the Overpolicing-Underpolicing Paradox in Brazil's Largest City
}

\author{
Thiago R. Oliveira ${ }^{1,2}$ \\ ${ }^{1}$ Department of Sociology, University of Surrey \\ ${ }^{2}$ Nuffield College, University of Oxford
}

\begin{abstract}
Residents of some neighborhoods often experience an overwhelming police presence that intrudes upon their lives, and yet feel unprotected by law enforcement agents who neglect safety provision, in a process named by the literature the overpolicing-underpolicing paradox. In the context of one of the most unequal cities in the world, this study provides a quantitative assessment of the dynamics and the consequences of this apparent paradox. Drawing upon a three-wave longitudinal survey representative of adult residents of eight neighborhoods in São Paulo, Brazil $(N=1,200)$, I demonstrate that perceptions of police intrusion and cynicism about police protection (a) dynamically reproduce each other over time, (b) share similar correlates, most notably related to exposure to structural disadvantage and aggressive policing practices, and (c) undermine beliefs about the legitimacy of the police. This study provides further evidence that the demand for public safety in disadvantaged communities does not seem to be solved by policing strategies centered around the increase of intrusive practices and highlights the relevance of exploring publicauthority relations in understudied Global South settings. I conclude with a discussion about how the unbalanced distribution of repression and protection by legal institutions can send relational messages of exclusion, marginalization, and neglect to members of the public.
\end{abstract}

\section{KEYWORDS}

overpolicing-underpolicing paradox, legal cynicism, police legitimacy, intrusive policing, Brazil.

\section{Correspondence}

Thiago R. Oliveira, Department of Sociology, University of Surrey, Guildford, Surrey GU2 7XH, United Kingdom. Email: t.oliveira@surrey.ac.uk

\section{Acknowledgements}

I would like to thank Jonathan Jackson, David S. Kirk, Jeffrey Fagan, Amy Nivette, Johann Koehler, Jouni Kuha, Charles C. Lanfear, Krisztián Pósch, members of the LSE Manheim Doctoral Working Group, and members of the Center for the Study of Violence (NEV-USP) for their invaluable feedback and critical read of earlier versions of this article. Earlier versions of this article were presented at the UCL London Policing Seminar Series, the University of Oxford's Latin American Centre Seminar Series, and the NIED/CERES Seminar Series. Data collection was carried out by researchers at NEV-USP with financial support of the 
São Paulo Research Foundation (CEPID-FAPESP 2013-07923-7); I thank Sergio Adorno for granting me access. The data and code necessary to replicate all the analyses are publicly available on the author's github page.

Ethnographic studies often describe how residents of some disadvantaged neighborhoods face an overwhelming presence of law enforcement agents in their daily lives. Reports of members of poor communities of color being repeatedly stopped, questioned, and harassed by police officers in cities like Chicago, Philadelphia, and New York City (Vargas, 2016; Carr et al., 2007; Haldipur, 2019) as well as in Latin America (Gonzáles, 2017; 2020) are frequent. Yet, at the same time, residents of such over-policed neighborhoods sometimes report high levels of fear of crime and unsafety (Bell, 2016; Campeau et al., 2020), which is often attributed to unresponsive policing. This suggests an unequal state distribution of repression and protection, with some over-policed communities also being under-protected: the police are overwhelmingly present, but neglect community residents and fail to ensure public safety. This is a process that Rios (2011) named the overpolicing-underpolicing paradox.

Using a longitudinal survey of adult residents in São Paulo, Brazil, this study provides a quantitative assessment of both the dynamics and the consequences of the overpolicing-underpolicing paradox in one of the largest and most unequal cities in the world. First, the underlying logic of this apparent paradox is that over- and under-policing are two sides of the same coin: race-class subjugated urban communities experience both predatory policing and high exposure to victimization (Bell, 2017). As such, the extent to which residents expect their neighborhoods to be, on the one hand, over-policed and, on the other hand, under-protected would consist of two positively rather than negatively correlated features of public perceptions of neighborhood policing (Boehme et al., 2022). To demonstrate these dynamics quantitatively, I investigate whether citizens' perceptions of police intrusion and cynicism about police protection are dynamically related, mutually reproducing each other over time; I also explore the extent which such perceptions are shaped by similar social forces, most notably related to exposure to concentrated disadvantage (Sampson et al., 1997) and aggressive policing practices (Oliveira, 2022). Understanding the dynamics of over- and under-policing is important for tackling a social problem faced by several unequal metropolitan areas: namely, that the demand for public safety in disadvantaged communities does not seem to be solved by policing strategies centered around the increase of intrusive presence.

Second, to explore some of the consequences of over- and under-policing, I investigate whether public perceptions of police intrusion and cynicism about police protection undermine beliefs about the 
legitimacy of legal institutions. Legitimacy judgements are crucial to the well-functioning of society (Tyler, 2006). When citizens recognize legal authority as the rightful authority, they tend to voluntarily comply with the laws (Papachristos et al., 2012; Jackson et al., 2012) and cooperate with legal institutions (Sunshine \& Tyler, 2003; Jackson et al., 2021); on the other hand, when citizens feel excluded from the group legal authority represents and develop antagonism and disengagement from law-related values, they can start to morally support alternative strategies of social control, including the use of interpersonal violence to resolve private and public matters (Jackson et al., 2013; Tankebe, 2009). I draw on procedural justice theory (PJT; Sunshine \& Tyler, 2003) to investigate how legal authority can gain or lose legitimacy depending on the extent to which its agents communicate to citizens that they are trustworthy to exercise power in normatively appropriate ways (Huq et al., 2017; Oliveira \& Jackson, 2021). In the context of a highly unequal city in the Global South, I investigate whether perceptions of police intrusion and cynicism about police protection, above and beyond expectations of procedural injustice, are negatively associated with police legitimacy. The underlying logic is that, by simultaneously over-policing and under-protecting some disadvantaged communities, legal institutions can operate to effectively exclude whole communities from the body politic (Bell, 2017, p. 2067) and send negative identity-related messages of oppression, marginalization, and neglect (Mackenzie, 2021; Oliveira \& Jackson, 2021).

This is particularly concerning in São Paulo, where fear of the police is central to public-authority relations (Jackson et al., 2022). Street-level policing is mostly conducted by the Polícia Militar de São Paulo (PMSP), an authoritarian and militarized force whose officers are trained for theatres of war (Gonzáles, 2020). In what can be described as an example of the increasing globalization of some policing tactics commonly adopted in the US across the Global South, policing methods are aggressive and centered around ideas of coercion and violence (Oliveira, 2022). People expect officers to use force even in routine circumstances (Jackson et al., 2022), and episodes of police brutality and killings are persistently common (Gonzáles, 2020). Like many other cities with high rates of interpersonal and state-sanctioned violence, São Paulo is a city where simultaneous reports of predatory policing and high exposure to crime are common (Gonzáles, 2017; Feltran, 2020).

Drawing upon unique data from a representative three-wave panel survey of adult residents of eight neighborhoods in São Paulo (2015-2018), this study seeks to answer questions about both the dynamics and the consequences of the overpolicing-underpolicing paradox in Brazil's largest city. First, do perceptions of police intrusion and cynicism about police protection mutually reproduce each over time, and do they share similar correlates? Second, do they undermine police legitimacy beliefs, above and beyond other known legitimating norms in São Paulo such as perceived procedural fairness? Findings of this paper contribute to current research on policing and legitimacy by (i) demonstrating that people 
perceive the distribution of police repression and protection in their communities as two opposite features of neighborhood policing; (ii) showing that, by overemphasizing repression provision and neglecting protection provision, law enforcement agents can contribute to weakening the social bonds between the public and legal authority; and (iii) highlighting the importance of investigating public-authority relations in other contexts in the Global South. In a context where urban violence still directly affects city life, this study describes how the persistence of the simultaneous over-policing and under-protection of some neighborhoods contribute to harm public legitimacy beliefs.

The paper proceeds as follows. I start by discussing dynamics of the overpolicing-underpolicing paradox, with a focus on the conceptual framing of perceptions of police intrusion and cynicism about police protection. I then move on to the discussion on consequences of the paradox, with a focus on undermined public legitimacy beliefs. In the next section, I discuss the São Paulo context and its substantive relevance to the literature on policing and legitimacy. Next, I present the data, methods, and measures; and then share results reflecting dynamics and consequences of the overpolicing-underpolicing paradox in São Paulo. Finally, I present the discussion and the conclusions, highlighting (i) the importance of addressing over- and under-policing issues to research on legitimacy and policing, (ii) the relevance of exploring other aspects of police conduct, beyond procedural fairness, that could enhance or harm legitimacy judgements, and (iii) the urgency of investigating public-authority relations in understudied Global South settings.

\section{1 | DYNAMICS OF THE OVERPOLICING-UNDERPOLICING PARADOX}

In an in-depth study based on direct observations, Rios (2011) described how policing was a common part of the lives of young African American and Latin boys in three neighborhoods in Oakland, California. They had frequent interactions with officers, recognized police hotspots in the community, heard of friends getting arrested; policing was somehow always present in their daily lives. Similarly, but in the context of New York City when the stop-and-frisk policy was at its peak, Haldipur (2019) reported how residents of racial minority communities in the Southwest Bronx often experienced multiple police stops a week, with officers constantly intruding upon their private lives. Policing was so deep-seated in some neighborhoods' culture that police behavior would become predictable and manipulable. For instance, Stuart (2016) showed that "copwise" residents of Los Angeles' Skid Row used this acquired wisdom and engaged in public behaviors in such a way so as to avoid police scrutiny.

These are just a few examples of ethnographic evidence on over-policed neighborhoods, where the state becomes deeply present in residents' everyday lives via punitive social control (Rios, 2011, p. 35). At the same time, residents of such neighborhoods often report precisely the opposite as well: state neglect. With high victimization rates, such locations usually are among the most unsafe urban communities, and residents not rarely perceive legal agents to be unresponsive and ill equipped to provide protection and 
security. In ethnographic study about policing and citizenship in several cities in Latin America, Gonzáles (2017, p. 500) shows how the lack of safety is often framed by community residents as the police's failure to provide citizens with their right to protection - and she quotes a woman in São Paulo who expressed cynicism about toward police during a local security council meeting: "What is being done so that we will be protected? We don't want to file police reports anymore, we want protection!" An 18-year-old girl from Philadelphia interviewed by Carr et al. (2007, pp. 458-459) summarized this perception of constant police intrusion combined with cynicism about police protection: "I see cops so often in my neighborhood, but when I see something bad going on, I look around and say 'where are the cops?'”.

This is an apparent paradox: neighborhoods can be characterized by both an excessive presence of police officers and malign neglect by those same officers. What Rios (2011) has named the overpolicingunderpolicing paradox involves intrusive and aggressive policing on a daily basis, and yet careless neglect about public safety; underserved and economically marginalized communities experiencing an overwhelming police presence that intrudes upon their lives but does very little to protect them and limit crime within their community. This scenario is often described in large and highly unequal urban centers in the US (Carr et al., 2007; Shedd, 2015; Bell, 2017), but also in several places in the Global South including Brazil’s largest city, São Paulo (Willis, 2009; Feltran, 2020; Gonzáles, 2020).

\subsection{Underpolicing and public cynicism about police protection}

Ethnographic evidence on the overpolicing-underpolicing paradox suggest that residents distrust the police and feel like legal agents cannot be reliant upon to provide their community with minimum public needs, such as public safety and security (Carr et al., 2007; Bell, 2016). Public beliefs that legal agents are not willing to allocate legal resources to ensure the protection of members of a community have been previously framed as legal cynicism by Kirk and Papachristos (2011). A concept originally developed by Sampson and Bartusch (1998), Kirk and Papachristos conceived of legal cynicism as a cultural frame through which people view the law and the legal institutions as unresponsive, illegitimate, and ill-equipped to ensure public safety (see also Kirk \& Matsuda, 2011; Kirk, 2016; Kirk et al., 2012). It is also a cultural, ecological attribute: through social interaction, this cultural frame becomes part of the social fabric of neighborhoods as people develop a shared orientation through which they make sense of the functioning of the law and the legal institutions.

Kirk and Papachristos (2011) built on but departed from the original conception of legal cynicism that focused on social norms and values. Sampson and Bartusch (1998) had previously drawn on the Durkheimian notion of anomie to define legal cynicism as "a state of normlessness in which the rules of 
the dominant society (and hence the legal system) are no longer biding in a community" (p. 782 ). ${ }^{1}$ On the other hand, Kirk and Papachristos focused on perceptions of the law and the legal institutions, emphasizing that sometimes individuals may believe in the substance of the law but have antagonistic views towards the agents of its enforcement. As a cultural frame, legal cynicism would then consist of the lens through which individuals observe, perceive, and interpret the performance of law enforcement agents in terms of their ability and interest in ensuring public safety.

The theory of legal cynicism is ecological, and this cultural frame would primarily be produced by neighborhood exposures to concentrated disadvantage and abusive policing. Cultural tools emerge as an adaptation to neighborhood structural conditions (Sampson \& Wilson, 1995): in economically deprived neighborhoods, people develop a shared understanding that legal institutions will not provide them with any type of security (Kirk \& Papachristos, 2011, p. 1198). Cynicism about the law is therefore fostered in neighborhoods where most residents are exposed to pervasive segregation and economic subjugation (Sampson \& Bartusch, 1998; Hagan et al., 2018). Similarly, neighborhood variation in the way justice is administered influences legal cynicism, particularly repeated police harassing behavior and insufficient attempts at controlling crime (Kirk \& Papachristos, 2011, p. 1199; Kubrin \& Weitzer, 2003; McCarthy et al., 2020). Residents then adapt to their neighborhood conditions and develop a cultural tool through which they interpret the functioning and viability of the law and the police, especially in terms of their (il)legitimacy, (un)responsiveness, and (in)ability to provide security and protection.

At its core, Kirk and Papachristos's (2011) conception of legal cynicism refers to public skepticism about the legal institutions' ability to ensure public safety; people are cynic of the law and the legal institutions when they perceive legal agents to act carelessly and disinterested in providing protection to community members (Hagan et al., 2018; 2020). This connects directly with some ethnographic evidence describing the 'underpolicing' part of the overpolicing-underpolicing paradox, as they often indicate that residents of some over-policed neighborhoods are skeptic about the ability of the police to ensure public safety (Rios, 2011; Bell, 2017; Carr et al., 2007).

To quantitatively measure public cynicism about police protection using survey data and assess the dynamics and consequences of the overpolicing-underpolicing paradox, I rely on the legal cynicism framework. Kirk and Papachristos (2011) originally measured legal cynicism by asking survey respondents

\footnotetext{
${ }^{1}$ This definition of legal cynicism has been widely used by the social sciences, including studies on topics such as neighborhood culture (Sampson, 2012; Kirk, 2016), police-citizen relations (Reisig et al., 2011; Gau, 2015), and legal socialization (e.g., Fagan \& Tyler, 2005; Fine \& Cauffman, 2015; Nivette et al., 2019).
} 
in Chicago about the degree to which they agreed with statements such as 'laws are meant to be broken', 'the police are not doing a good job in preventing crime in this neighborhood', and 'the police are not able to maintain order on the streets and sidewalks in the neighborhood'. Other studies adapted that scale to other contexts. For instance, Hagan et al. (2016) measured legal cynicism about US/Coalition forces among Arab Sunni civilians in post-invasion Iraq using survey items loosely tapping into legitimacy, responsiveness, and security. In this study, I draw on data from a three-wave longitudinal survey of São Paulo residents and measure cynicism about police protection using an adapted scale based on survey items asking respondents to react statements such as 'laws protect me', 'the police in my neighborhood ensure my safety', and 'the police are doing a good job in keeping the streets of my neighborhood peaceful'.

\section{2 | Overpolicing and public perceptions of police intrusion}

Rios (2011) suggests that predatory policing is a constant part of young people's lives in some disadvantaged neighborhood. According to ethnographic evidence on the overpolicing-underpolicing paradox, residents of such over-policed neighborhoods feel an overwhelming police presence that intrudes upon their lives to the extent that policing becomes part of their daily routines (Carr et al., 2007; Bell, 2016; Stuart, 2016). Perceptions of an over-policed environment therefore relate to beliefs that law enforcement agents frequently intrude upon the lives of people in a neighborhood, harassing residents, giving too much attention to petty illegalities, and acting as if they were above the law.

Public perceptions of police intrusion have previously been studied by procedural justice and legitimacy scholars. For instance, in a study with young men aged 18-26 in New York City, Tyler, Fagan, and Geller (2014) explored respondents' generalized neighborhood experiences with police and measured their overall expectations of intrusiveness during police stops. Perceived police intrusion was measured using survey items asking how often the police in their neighborhood "physically search people," "use harsh or insulting language," "threaten to use physical force," "take out a weapon, such as a gun, a club or a taser," "treat people disrespectfully," and "bully or intimidate people." Similarly, using data from a survey representative of the US adult population, Tyler, Jackson, and Mentovich (2015) investigated the degree to which people believed that police officers would normally treat them as objects of suspicion. To measure what they labelled as perceptions of personalized police suspicion, they used survey items asking whether the police "are generally suspicious of people like you," treat people like you as if you were probably doing something wrong," and "treat people like you as if you might be dangerous or violent."

Specifically measuring public perceptions of overpolicing, Boehme et al. (2022) focused on perceptions of excessive use-of-force and asked Chicago residents "how much of a problem is excessive use of force by the police (in your neighborhood)". More recently, scholars have focused on widespread 
perceptions that police officers tend to intrusively overstep their authority beyond normative boundaries of appropriate police behavior. Extending relational norms beyond fair process, Trinkner and colleagues suggested that people do not just judge how law enforcement agents exercise power, but also what power is being exerted when and where (Trinkner et al., 2018; Tyler \& Trinkner, 2017). Framing such expectations as perceived bounded authority, Trinkner, Jackson, and Tyler (2018) measured this construct using survey items asking respondents how often the police "respect people's rights," "arrest people for no good reason," and "behave according to the law when they deal with people."

In common, all these latent constructs reflect public expectations that police officers tend to intrude upon the lives of neighborhood residents - overstepping their authority, paying too much attention to petty illegalities, engaging in intimidatory practices. They are linked to an excessive state provision of repression: police officers make themselves present in the neighborhood, but over-regulating public behavior (Fagan et al., 2016). As task-specific expectations of police behavior, public perceptions of police intrusion are partly produced by direct and indirect experiences of police intrusion throughout the life course (Oliveira \& Jackson, 2021) - such as vicarious neighborhood exposures and direct public-police interactions in which law enforcement agents are perceived to exert power in intrusive and intimidatory ways. I develop this point in the next section, but the premise here is that exposures to police conduct consist of teachable moments in which values that are important to the legal institutions are passed on (Tyler et al., 2014).

Additionally, previous research on neighborhood effects suggests that neighborhood variation in policing is a product of structural conditions of neighborhoods (Kirk \& Papachristos, 2011; Kirk \& Matsuda, 2011), with residents of more disadvantaged places receiving substantially more police scrutiny (Sharkey, 2018; Shedd, 2015). For instance, based on systematic social observation of police in Indianapolis, Indiana, and St. Petersburg, Florida, Terrill and Reisig (2003) showed that police officers tended to use high levels of force more frequently in disadvantaged neighborhoods, and Omori, Lautenschlager, and Stoler (2022) analyzed stop-and-frisk data from the New York City Police Department between 2006 and 2012 and demonstrated that police use force more often in Black and Latinx neighborhoods. In São Paulo, 15\% of the city districts - each of them characterized by high levels of concentrated disadvantage and racial diversity - accounted for 50\% of all police killings in 2014 (Sinhoretto et al., 2016).

This study conceptually frames perceptions of overpolicing as public expectations of police intrusion - e.g., the extent to which community residents believe that police officers tend to interfere in their neighbors' and their own lives. Adapting from previous research measuring similar constructs, I rely on survey items asking São Paulo residents about the degree to which they believed that police officers in their neighborhoods 'follow and harass people' and 'act as if they were above the law.' 


\section{2 | CONSEQUENCES OF THE OVERPOLICING-UNDERPOLICING PARADOX}

\subsection{Delegitimation of legal institutions}

After exploring the dynamics public perceptions of overpolicing and cynicism about police protection, I investigate one potential consequence of the overpolicing-underpolicing paradox; namely, the undermine of public beliefs about the legitimacy of legal institutions. The legitimacy of an authority figure can be defined as the recognition, in the eyes of those who are asked to abide, of its right to govern (Coicaud, 2002; Beetham, 2013). Applied to legal institutions, this implies that it is the citizens, who are subject to the power of the law, who judge legal authority's claim to power (Jackson \& Bradford, 2019). Such empirical judgements generally refer to both assent and consent to the law's right to govern - i.e., they reflect whether citizens believe that legal institutions share their normative values about the appropriate exercise of power and whether they accept legal authority's right to dictate appropriate public behavior (Tyler, 2006; Tyler \& Jackson, 2014). Therefore, to gain legitimacy, agents of the law need to communicate to citizens that they share and respect public normative expectations about the proper exercise of legal power. To the extent that people believe that law enforcement agents are trustworthy to exert power in normatively appropriate ways (i.e., respecting key legitimating norms), their judgements about the legitimacy of the law and the legal institutions are enhanced (Trinkner et al., 2018; Oliveira et al., 2021). Figure 1 graphically displays this theoretical framework.

[FIGURE 1 HERE]

What exact criteria people use to judge the normative appropriateness of the exercise of authority is an empirical question (Trinkner, 2019), and expectations about how power should be wielded tend to be a product of neighborhood exposure to structural conditions and life-course experiences with the law (Oliveira \& Jackson, 2021). According to Tyler's relational account of police legitimacy, legal institutions can build legitimacy when they exert power with procedural fairness (Tyler, 2006; Sunshine \& Tyler, 2003). PJT is grounded on the group value model and the group engagement model (Lind \& Tyler, 1988; Tyler \& Blader, 2000), which highlight the importance of identity-relevant normative police conduct. Essentially, legal agents enhance public legitimacy beliefs by signaling to citizens that they are a valued part of the group legal authority represents. When agents of the law emphasize high-quality interpersonal treatment (treating citizens with respect and dignity) and decision-making (making decisions in open, transparent, and neutral ways, and taking citizens' concerns into account), they communicate status and value, signaling to citizens that they are valued members of society and therefore strengthening the social bonds between individuals, authority figures, and the superordinate group that legal institutions represent (Lind \& Tyler, 1988; Tyler \& Huo, 2002). Empirically, perceptions of police procedural fairness are generally found to be strongly associated with scores reflecting legitimacy beliefs (see Jackson, 2018 for a review of the 
international literature; see Mazerolle et al., 2013 for a meta-analysis), including in Brazil (see Jackson et al., 2022; Trinkner et al., 2020; Oliveira et al., 2020).

Yet, there might be other elements of police conduct beyond procedural fairness that could also send relevant identity-related messages to members of the public and thus enhance or undermine public judgements about the legitimacy of legal authority (Huq et al., 2017; Oliveira \& Jackson, 2021). I build on Mackenzie's (2021) point that messages of oppression, marginalization, and neglect have special moral significance, as they can potentially shape people's identities, autonomy, and sense of self-respect.

By repeatedly engaging in predatory policing practices and interfering in the lives of community residents, officers can send messages of oppression and marginalization, propelling some people to a cultural understanding the functioning of the law not in terms of safeguard and protection, but in terms of confrontation and intrusion. Indeed, Tyler et al. (2014, p. 766) showed that "more police intrusion of any type in the lives of people in the neighborhood was linked to lower legitimacy," and Trinkner et al. (2018, p. 4) suggested that "increased intrusion by legal authorities can be in-and-of-itself delegitimizing." Similarly, when legal agents are perceived to act disinterested in providing communities with basic goods such as protection and security and ensuring public safety, they can pass on messages of marginalization and neglect - which could lead to widespread expectations that law enforcement agents operate to exclude disadvantaged groups, including poor communities of color, from society (Bell, 2017). For example, Carr et al. (2007, p. 459), while discussing sources of negative disposition toward police among members of underprivileged communities in Philadelphia, mentioned that some respondents "complained about slow response and echoed a sense of underpolicing often common in disadvantaged neighborhoods."

Above and beyond procedural fairness, when citizens expect officers to repeatedly intrude upon neighborhood residents' lives and at the same time are cynic about their ability to ensure public safety, legal agents can contribute to a sense of otherness and group exclusion, weakening the social bonds between individuals and legal authority. This could contribute to the reproduction of cultural orientations toward the law based on an understanding that "the legal system and law enforcement, as the individual's group experiences these institutions, are fundamentally flawed and chaotic, and therefore send negative messages about the group's societal belonging" (Bell, 2017, pp. 2086-2087). The overpolicing-underpolicing paradox could therefore play an important role in the delegitimation of the law and the legal institutions.

\section{3 | POLICING AND VIOLENCE IN SÃO PAULO, BRAZIL}

With more than 20 million people in the metropolitan region, São Paulo is one of the largest and most unequal cities in the world (Marques, 2016). Nationally, Brazil is an extremely violent country: it has an average homicide rate of 27.8 per 100,000 habitants (Cerqueira et al., 2020) and the largest number of victims of murder in South America (UNODC, 2013). Yet, Brazil's largest city has substantively different 
figures: after a huge drop in the 2000s, the homicide rate in São Paulo is around 10 per 100,000 (Nery et al., 2012) - considerably lower than in cities like Philadelphia, Chicago, or Washington, D.C. However, despite this relatively low rate, São Paulo is a city where violence is pervasive and part of its social fabric (Feltran, 2020) and where even the rule of law is unevenly distributed (Willis, 2015). While in most neighborhoods legal institutions function properly, in several peripherical communities increasingly bureaucratized criminal gangs have started to claim legitimacy and occupy a power vacuum where the state has been negligent (Manso \& Dias, 2018). Organized crime governs extensively, ruling large urban populations across enormous swaths of territory (Lessing \& Willis, 2019) and providing residents with security and protection (Feltran, 2020). In areas where they dominate, criminal gangs impose their own set of rules and procedures, ${ }^{2}$ governing through coercion and the constant threat of violence (Dias \& Darke, 2016). Either through crime victimization or criminal gangs, legal socialization in São Paulo can be characterized by frequent exposures to violence (Oliveira et al., 2022).

On the other hand, legal institutions are also overwhelmingly present in the lives of most residents. Street-level policing is mostly conducted by the Polícia Militar de São Paulo (PMSP), an authoritarian and militarized organization that relies heavily on aggressive and confrontational tactics to tackle crime (Gonzáles, 2020; Oliveira, 2022). Every police officer ${ }^{3}$ carries a firearm (Pinc, 2006), and survey estimates suggest that around half of all investigatory police stops in the city tends to involve officers pointing a gun at the citizen (Oliveira, 2022). Gonzáles (2020, p. 77) suggests that the PMSP "exemplifies the stubborn persistence of distinctly authoritarian modes of coercion." Beyond aggressive policing tactics, police violence - including police killings - remains one of the most distinctive characteristics of the PMSP: in 2017, 940 civilians were killed by (on and off duty) police officers (Mariano, 2018), a similar number of deadly victims of police violence in the entire United States in 2016 (Gonzáles, 2020); according to the Anuário Brasileiro de Segurança Pública 2021, out of the more than 8 thousand violent deaths in the city in 2020, almost $10 \%$ were police killings. ${ }^{4}$ Accordingly, fear of the police is high, and a public image of the institution as "just violent another gang" has cultural currency (Jackson et al., 2022).

\footnotetext{
${ }^{2}$ Rules and procedures include, for instance, the prohibition of killings (Dias \& Darke, 2016). Previous work suggests that organized crime is at least partly responsible for the huge homicide drop in the 2000s (Biderman et al., 2018).

${ }^{3}$ With 83,000 sworn officers, the PMSP operates under a rate of one officer for every 530 residents in the state of São Paulo The PMSP is the police department in charge of street-level policing in the whole state of São Paulo, not just the city. For comparison purposes, the Chicago Police Department has approximately 12,000 sworn officers and a rate of one officer for every 220 residents, and the Philadelphia Police Department has approximately 6,300 sworn officers and a rate of one officer for every 250 residents.

${ }^{4}$ Available at https://forumseguranca.org.br/wp-content/uploads/2021/07/anuario-2021-completo-v6-bx.pdf.
} 
In this context, state provision of repression and protection can shape how individuals experience citizenship: according to Gonzáles (2017, p. 495), deficient and unequal security provision produces constrained and stratified citizenship - effectively excluding some groups of people from the body politic. Potentially as a consequence, public support for authoritarianism has increased over the past years, ${ }^{5}$ including tolerant views about use of violence and threats to the rule of law (Adorno, 2013). At the same time, public support for police brutality is also popular, especially in disadvantaged (and, paradoxically, over-policed) neighborhoods (Caldeira, 2002); for example, Gonzáles (2017, p. 502) describes that during a local security meeting in a low-income neighborhood in São Paulo, after a police officer announced that a suspect had been shot and killed, residents reacted with applause and support. The notion that the state exaggerates the distribution of oppression through heavy-handed policing and at the same time neglects its responsibility to provide protection can lead some citizens to a cultural understanding that they need to rely on alternative means to provide for their own security (Kirk \& Papachristos, 2011).

\subsection{Police legitimacy in São Paulo as a coercive-consensual continuum}

Jackson et al. (2022) explored the nature of public beliefs about the legitimacy of legal institutions among São Paulo residents. Scholars measuring legitimacy beliefs usually seek to distinguish between legitimacybased reasons to obey the law (grounded on normative recognition of legal authority as the rightful authority) and coercive-based motivations to obey (grounded on fear and instrumental obedience) (e.g., Pósch et al., 2020). But in São Paulo, echoing the current style of policing tactics that often combine consensual and coercive elements, the two motivations could not be empirically differentiated; instead, they formed one bipolar scale moving from instrumental and fear-based reasons to normative and legitimacybased reasons to obey police officers' commands (Jackson et al., 2022).

The authors developed a novel measurement model of police legitimacy using a latent trait analysis approach. First, they conducted a content analysis of an open-ended question asking why respondents thought they should/should not obey the police even when they thought the police were wrong. Responses of those who said they should obey the police were classified either as 'normative duty to obey' or as 'coercive obligation,' whereas responses of those said they should not obey the police were classified as a type of either 'disobedient protest' or 'rejection of authority' (see also Oliveira et al., 2020). They then combined this nominal four-category variable with other survey items tapping into normative alignment

\footnotetext{
5 "Medo da violência e o apoio ao autoritarismo no Brasil: índice de propensão ao apoio a posições autoritárias", Fórum Brasileiro de Segurança Pública (2017), https://forumseguranca.org.br/wpcontent/uploads/2019/04/FBSP_indice_propensao_apoio_posicoes_autoritarios_2017_relatorio.pdf.
} 
with the police and fear of the police and fit latent trait models. Finally, reflecting the nature of policecitizen relations in São Paulo, they demonstrated how a one-trait solution, which they labelled a 'coerciveconsensual continuum,' had the best model fit. Normative alignment and the 'normative duty to obey' and 'disobedient protest' categories had positive trait loadings, whereas fear of the police and the 'coercive obligation' and 'rejection of authority' categories had negative trait loadings. This suggests that people who fell on the negative side of the continuum tended to fear police, believed that officers usually act in normatively inappropriate ways, and reported an instrumental obligation to obey officers; people in the middle of the scale exhibited an ambivalent mix of both instrumental and normative connections to the police; and people in the positive side of the continuum had normative connections based on the belief that officers act in normatively appropriate ways and that police have rightful authority. The authors also demonstrated how their novel measure of police legitimacy neatly predicted public willingness to voluntarily comply with the law in São Paulo (Jackson et al. 2022).

In this study, I build on this previous work and operationalize public beliefs about the legitimacy of the police among São Paulo residents as a coercive-consensual continuum. Using the same survey items tapping into normative alignment and fear of the police as well as an open-ended question asking about respondents' motivation to obey the police (using the same four categories, which were obtained based on a machine learning text classification model), I replicate their latent trait analysis and use trait scores reflecting the coercive-consensual continuum to investigate whether perceptions of police intrusion and cynicism about police protection are negatively associated with police legitimacy beliefs.

\section{4 | CURRENT STUDY}

I investigate the dynamics and consequences of the overpolicing-underpolicing paradox in the context of eight neighborhoods in São Paulo. First, this study asks whether perceptions of police intrusion and widespread cynicism about police protection form two complementary rather than antagonistic features of public perceptions of neighborhood policing by exploring the degree to which they mutually reproduce each other over time, and whether they share similar correlates. Second, it focuses on the consequences of perceptions of overpolicing and legal cynicism and explores whether they contribute to undermine public recognition of the law enforcement agencies' right to enforce the law. Figure 2 translates the argument into a conceptual model.

\section{[FIGURE 2 ABOUT HERE]}

First, dynamics of the over- and under-policing. I build on the ethnographic evidence from previous work (e.g., Rios, 2011; Carr et al., 2007) and examine whether perceptions of police intrusion and cynicism about police protection are complementary rather than antagonistic features of perceptions of police in some neighborhoods. Public expectations that police officers will repeatedly intrude upon the lives of 
neighborhood residents could increase the perceptions that law enforcement agents neglect people in their community; but, likewise, widespread cynicism about the ability of legal institutions to ensure public safety could be associated with beliefs that officers constantly overstep their authority. My hypothesis is that perceptions of over-policing and under-policing reproduce each other over time, somewhat following the logic of a vicious cycle. Making use of longitudinal data from eight neighborhoods in São Paulo, I assess the extent to which changes in perceived police intrusion and cynicism about police protection are reciprocally related.

- Hypothesis 1.1: Changes in perceived police intrusion are positively associated with changes in cynicism about police protection.

- Hypothesis 1.2 Changes in cynicism about police protection are positively associated with changes in perceived police intrusion.

Still focused on the dynamics of the overpolicing-underpolicing paradox, I rely upon both the legal cynicism and the procedural justice literatures to investigate the predictors of perceptions of police intrusion and cynicism about police protection and explore whether they are produced by similar social forces. Legal cynicism is a cultural frame partly produced by exposure to both concentrated disadvantage and neighborhood variation in police behavior (Kirk \& Papachristos, 2011; Kirk \& Matsuda, 2011). In addition, variation in policing is informed by neighborhood structural conditions, with poorer communities being consistently more over-policed (Suss \& Oliveira, 2022; Kane, 2005). Finally, exposures to police conduct consist of teachable moments in which legal authority's values are passed on (Tyler et al., 2014). For instance, the experience of being stopped by the police at gunpoint - an aggressive and surprisingly frequent experience among São Paulo residents (Oliveira, 2022) - could signal to citizens that they are not valued members of society. As such, residents of more economically deprived neighborhoods and those who were more exposed to abusive policing practices should have higher scores of both cynicism about police protection and perceptions of police intrusion.

- Hypothesis 1.3: Residents of neighborhoods characterized by more structural disadvantage have higher average scores of cynicism about police protection.

- Hypothesis 1.4: Residents of neighborhoods characterized by more structural disadvantage have higher average scores of perceived police intrusion.

- Hypothesis 1.5: A recent police stop at gunpoint is associated with increases in scores of cynicism about police protection.

- Hypothesis 1.6: A recent police stop at gunpoint is associated with increases in scores of perceived police intrusion.

The second part focuses on the consequences of the over- and under-policing. My hypothesis is that perceptions of police intrusion and cynicism about police protection undermine public beliefs about 
the legitimacy of legal institutions. The rationale here is twofold. First, I anticipate that expectations of over- and under-policing consist of (de)legitimatizing norms: people expect legal power to be exerted without the twin harms of excess and neglect. Second, I hypothesize that the unfair distribution of repression and protection sends negative identity-related messages of marginalization and carelessness which could signal to members of the public that they do not belong in the superordinate group that legal institutions represent (Mackenzie, 2021). The context is the city of São Paulo, where policing's governing principle involves undue coercion, so police legitimacy is measured as a coercive-consensual continuum (Jackson et al., 2022). To test this set of hypotheses, models need to be adjusted for other known legitimating norms in the context, such as perceptions of procedural fairness (Oliveira et al., 2020).

- Hypothesis 2.1: Cynicism about police protection is negatively associated with police legitimacy judgements, net of perceptions of procedural fairness.

- Hypothesis 2.2: Perceptions of police intrusion are negatively associated with police legitimacy judgements, net of perceptions of procedural fairness.

\subsection{Data and methods}

I draw upon data from a three-wave population-based survey representative of residents of eight neighborhoods in São Paulo in 2015, 2017, and 2018, ${ }^{6}$ on the extent and nature of citizens' experiences with the police and their attitudes towards the law and legal institutions (see Oliveira et al., 2019). Given that dynamics of over- and under-policing should vary considerably by neighborhood, sampling procedures build on a previous study about São Paulo's extremely high levels of spatial heterogeneity (Nery et al., 2019).

After making census data from 1980 to 2010 compatible at the census tract level, Nery et al. (2019) performed a cluster analysis of nearly 20,000 tracts in the city using information about their urban, criminal, demographic, and structural conditions. The authors found eight patterns in the city - i.e., eight categorical types of neighborhoods, each highly homogeneous but very distinct from each other - and made the point that nonprobability survey designs often under-represent some and over-represent other types. For each of those eight types of neighborhoods, the authors selected a highly representative contiguous area with about 20 to 50 census tracts each and referred to these contiguous areas as key areas; they were designed to substantively represent the eight (urban, criminal, demographic, and structural) patterns that form the city of São Paulo. In the current study, sampling procedures were employed to represent adults residing in the eight key areas.

\footnotetext{
${ }^{6}$ The gap between waves of data is approximately 18 months.
} 
In each key area, a two-stage cluster sampling design was used: the first stage involved randomly selecting ten census tracts based on a systematic probability proportional to size (PPS); the second stage involved selecting 150 respondents, each following demographic quotas calculated based on census information (gender, age, and education). ${ }^{7}$ In mid-2015, 150 adult residents were selected in each area, thus totaling a sample of 1,200 respondents. In early 2017, 928 of those responded to the second wave of the longitudinal study; in mid-2018, 801 respondents took part in the third wave of data collection. The attrition rates of $22.7 \%$ and $13.7 \%$ are lower than the rate of $25 \%$ which was expected by the researchers. I assume dropouts to be missing at random. ${ }^{8}$ The sample is fairly representative of the adult population in each of the eight areas; and even though it was not designed to represent the adult population residing in the city of São Paulo, demographic characteristics are similar: $53 \%$ of the respondents are female $(52.7 \%$ in the population), $56 \%$ are white (60.6\% in the population), and the average age is 40.2 years (37 years in the population). $9 \%$ of the respondents belong to social class $\mathrm{A}^{9}$, the wealthiest segment of society, $8 \%$ to social class B1, 24\% to social class B2, 25\% to social class C1, 24\% to social class C2, and $10 \%$ to social classes $\mathrm{D}$ and $\mathrm{E}$, the most economically deprived.

\section{2 | Variables and measurement strategies}

- Underpolicing: cynicism about police protection

To measure perceptions of underpolicing, respondents were asked to react to statements tapping into feelings of cynicism about police protection. Adapting from Kirk and Papachristos' (2011) legal cynicism scale, survey items reflect perceptions about both the law and the legal institutions: "laws protect me,"

\footnotetext{
${ }^{7}$ In each selected census tract, interviewers randomly selected one household to start, and then went door to door asking residents to take part in the study until they completed their demographic quotas. Unfortunately, the company hired to conduct the data collection did not report the refusal rate. All interviews were conducted face-to-face, in Portuguese, at the respondents' place of residence using Tablet-Assisted Personal Interviewing (TAPI).

${ }^{8}$ A binomial logistic regression model predicting dropouts at the second wave indicates no association between perceptions of perceptions of police intrusion at T1, gender, race, social class, or age and the probability of dropping out at T2. The only significant predictor was perceived cynicism about police protection at T1: an increase of one standard deviation in the scores of this variable was associated with a decrease of $4.6 \%$ in the probability of dropping out (marginal effects at the mean). Respondents at T2 have slightly more negative views of the police. In terms of the probability of dropping out at $\mathrm{T} 3$, the only significant predictor was age, where every year was associated with a small decrease of $0.3 \%$ in the probability of dropping out.

${ }^{9}$ Social classes are assigned following the Critério Brasil, a system of social class assignment based on respondents' economic positioning and buying power. It consists of a point-based system for the economic classification of households developed by the Brazilian Market Research Association (ABEP). In 2016, D-E households had an average monthly income of 768 BRL (approximately 230 USD) while A households had an average monthly income of 20,888 BRL (approximately 6,420 USD). The CCEB 2016 report is available at http://www.abep.org/criterio-brasil (visited on $01 / 08 / 2021)$.
} 
"police in my neighborhood ensure my safety," and "the police are doing a good job in keeping the streets of my neighborhood peaceful." Items were measured using a five-point Likert scale (ranging from "strongly agree" to "strongly disagree" for the former two items and from "very good" to "very bad" for the latter). Measurement modelling is conducted using pooled confirmatory factor analysis (CFA) to ensure longitudinal equivalency. The pairwise likelihood method was used to handle ordinal indicators and missing data with logistic function links (Katsikatsou et al., 2012). Derived factor scores reflecting cynicism about police protection are then used throughout the manuscript. A full account of the measurement models can be found in Appendix A, and a list of all survey items used in this study can be found in Table 1 .

- Overpolicing: perceptions of police intrusion

To measure perceptions of overpolicing, respondents were asked to react to statements tapping into expected police intrusion. Adapting from Tyler et al.'s (2014) scale of perceived police intrusion, Tyler et al.'s (2015) scale of perceived police suspicion, and Trinkner et al's (2018) scale of perceived bounded authority, survey items indicate that police officers in their neighborhood "act as if they were above the law" and "follow and harass people," each measured using a five-point Likert scale ranging from "strongly disagree' to 'strongly agree.' Measurement modeling follows a similar analytic strategy: pooled graded response models for polytomous data using logistic function links, with derived trait scores reflecting perceptions of police intrusion subsequently used.

- Police legitimacy (coercive-consensual continuum) 
To measure beliefs about the legitimacy of the police among São Paulo residents, I replicate Jackson et al.'s (2022) measurement model and estimate a coercive-consensual continuum. This construct is measured by the same survey items used by Jackson et al. (2022), ${ }^{10}$ including items tapping into normative alignment with the police ("the police act in accordance with what you believe is right and wrong") and fear of the police ("people are afraid of the police"), each measured using a five-point Likert scale ranging from "never" to "always"), as well as a binary indicator of duty to obey the police ("do you think you should obey the police even when you believe they are wrong") and a nominal indicator of duty to obey reflecting the reason why respondents thought they should ('normative duty to obey' or coercive obligation') or should not ('disobedient protest' or 'rejection of authority') obey the police - these four categories were obtained using a supervised machine learning text classification model based on Jackson et al.'s (2022) and Oliveira et al.'s (2020) original content analysis. All these indicators were used in a pooled latent trait model estimated using maximum likelihood, and derived trait scores were subsequently used to measure police legitimacy beliefs. Higher scores indicate police legitimacy, as reflected by respondents who believe that legal authority is appropriate and should be obeyed based on normative reasoning. Lower scores indicate instrumental and coercive motivations to comply with legal directives, as reflected by respondents who are fearful of the police, believe officers should only be obeyed out fear of sanction or violence, and do not share values with legal authority. A description of the measurement model can be found in Appendix A.

- Time-varying covariates

To measure recent exposure to aggressive policing practices, I use a binary indicator reflecting whether respondents recently experienced a resident-police interaction at gunpoint. Respondents were first asked whether they "were stopped by the police (over the last two years/since our last interview) in the state of São Paulo" (yes or no). Those who answered 'yes' were then further asked whether during that stop "police officers pointed a gun" at them (again, yes or no). While this practice might seem too extreme and rare from a western perspective, it is not uncommon for police stops in Brazil to involve the threat of firearm use: while about one third of the respondents reported having been stopped by the police, almost half (47.1\%) of those self-reported encounters involved a gun being pointed at them (see Oliveira, 2022).

Another key time-varying covariate included expected police conduct, particularly in terms of perceived procedural fairness. A full account of measurement models assessing the scaling properties and

\footnotetext{
10 Two surveys were fielded using the same instrument: a 2015 cross-sectional representative survey of the adult population residing in the city of São Paulo and a three-wave panel survey representative of the adult population residing in eight neighborhoods in the city of São Paulo. The original content analysis of open-ended responses was conducted considering the cross-sectional data (see Oliveira et al., 2020; Jackson et al., 2022).
} 
empirical distinctiveness of latent variables can be found in Appendix A. This construct was also measured using a pooled CFA model with pairwise likelihood and factor scores then used in subsequent analysis.

- Time-constant covariates

Other covariates included are constant over time at the individual level. One of them is the neighborhood where respondents live, coded as the eight key areas used in the survey design (only respondents who did not move to a different neighborhood were contacted at waves 2 and 3). Because of how the eight key areas were selected, they are proxy for structural differences between neighborhoods (Nery et al., 2019). Other individual-level covariates are self-reported race, ${ }^{11}$ biological sex, and estimated social class.

[TABLE 1 HERE]

\section{5 | POLICE-CITIZEN RELATIONS BY NEIGHBORHOOD}

Table 2 displays some information about the eight neighborhoods, including descriptive statistics of key variables. It is possible to see how different the neighborhoods are, both demographically and in terms of perceived police conduct. Areas 1 through 4 are characterized by different levels of structural disadvantage, with a high proportion of young residents and high homicide rates (both in the area itself and in neighboring locations). Most residents belong to social class C1 or lower. In line with previous knowledge about Brazilian demographics, these areas also tend to be more racially diverse, with about half of their residents self-reporting as white. Area 4 is the only distinctively non-white neighborhood, with only $31 \%$ of the respondents self-defining as white.

[TABLE 2 ABOUT HERE]

These areas are also characterized by an excessive police presence. On average, between one third and half of residents of these neighborhoods reported being recently stopped and questioned by PMSP officers, and around half of all those stops involved an officer pointing a gun at residents. In the distinctively non-white area 4, 65\% of all recent self-reported police stops were at gunpoint. Residents also tend to perceive officers repeatedly intruding upon the lives of their neighbors to a greater extent than residents of other areas, as well as higher levels of cynicism about the ability of the police to ensure public safety.

Areas 5 and 6 are characterized by less structural disadvantage. With lower homicide rates and fewer young people residing in the neighborhood, most residents belong to social classes B2 and C1. Area

\footnotetext{
11 There are officially five racial groups: white (caucasian), black (afro-descendant), mixed race, asian-descendant, and indigenous. I dichotomize racial groups for the sake of simplicity and because whiteness is what more clearly communicates social privileges in Brazil, but by no means do I imply that the other four groups are homogeneous. For a discussion on racial inequality in Brazil, including how to measure racial identities, see Bailey et al. (2013).
} 
5 is also racially diverse, with approximately half of its residents self-identifying as white, while area 6 is a more predominantly white neighborhood: two thirds of the respondents residing in this area self-identify as white. Residents' perceptions of police intrusion and cynicism about police protection seem substantially lower than those of residents of areas 1 through 4; yet, even in such areas police conduct seems to rely on aggressive strategies, as respectively $50 \%$ and $40 \%$ of all recent self-reported police stops in areas 5 and 6 happened at gunpoint.

By contrast, areas 7 and 8 constitute wealthier neighborhoods. With a predominantly white population ( $80 \%$ and $87 \%$, respectively), these areas are characterized by lower levels of violence and residents who belong to wealthier segments of society (mostly to social classes A, B1, and B2). Residents also feel considerably less over-policed and under-policed and are stopped and questioned by police officers less frequently than residents of other neighborhoods. In comparison, police conduct seems to rely less on aggressive practices in these areas, as approximately one quarter of all self-reported police stops involved an officer pointing a gun at residents. Yet, these numbers reflect how coercive police behavior generally is in São Paulo: even in wealthier neighborhoods, police officers drawing their firearms during police stops is astonishingly common.

\section{6 | FIRST PART: DYNAMICS OF OVERPOLICING AND UNDERPOLICING}

\section{1 | Estimation strategy}

The first set of hypotheses state that perceptions of police intrusion and cynicism about police protection are mutually dependent, reproducing each other. ${ }^{12}$ In order to assess this reciprocal relationship, I investigate whether changes in perceptions of police intrusion are associated with changes in cynicism in police protections and, likewise, whether changes in cynicism about police protection are associated with changes in perceptions of police protection.

The standard estimation strategy to depict reciprocal relationships involves fitting a cross-lagged panel model (CLPM). However, CLPMs have recently been criticized because the inclusion of autoregressive parameters alone is not enough to handle stable between-unit differences. To overcome this issue, I rely on Allison et al's (2017) dynamic panel model with fixed effects estimated with maximum

\footnotetext{
${ }^{12}$ Previous research has framed this type of mutual relationship as Granger or reverse causality (Hamaker et al., 2015), although such relationships cannot be causal as they form a cyclic relationship (Morgan \& Winship, 2015). Considering the causal inference literature, there are no statistical methods that can depict mutual causal relationships (VanderWeele, 2015). For this reason, I refrain from implying mutual causation and use the expression reciprocal relationship instead.
} 
likelihood using the structural equation modeling framework (ML-SEM). ${ }^{13}$ The ML-SEM models timeconstant between-unit differences using a latent variable reflected by scores of the dependent variable at each time point (except the first one) with loadings constrained to 1 that is correlated with all independent variables, thus effectively functioning in a manner equivalent to standard fixed-effect estimators and controlling for time-constant unobserved heterogeneity (Allison, 2009). Crucially, the ML-SEM method allows for reverse causality by assuming sequential exogeneity, which means that estimates are not biased to potential effects of the dependent variable on the explanatory variables over time. According to Lesczensky and Wolbring (2019), this is the best analytic strategy to handle reverse causality.

Following Allison et al.'s (2017) recommendation to explore reciprocal relationship, this study fits two separate ML-SEM models: M1 focuses on the effects of cynicism about police protection on perceptions of police intrusion; M2 focuses on the effects of perceptions of police intrusion on cynicism about police protection. Each model accounts for temporal stability of latent constructs, control for timeconstant unobserved heterogeneity, and focuses on changes over time. As such, M1 and M2 should provide strong evidence for or against hypotheses 1.1 and 1.2. In addition, each M1 and M2 include a set of important independent variables that permit the assessment of hypotheses 1.3 through 1.6. Such independent variables are either time-varying - such as whether respondents self-reportedly experienced a recent police stop at gunpoint - or time-constant, including dummy variables for the neighborhoods where the study took place, self-reported race, gender, and social class. Robust standard errors are used to address potential heteroskedasticity, and full information maximum likelihood is used to handle missing data. ${ }^{14}$

\section{$6.2 \mid$ Results}

Two ML-SEM models were fitted: M1, predicting cynicism about police protection; and M2, predicting perceptions of police intrusion. Results from both models are partially displayed in Figures 3 and 4 . Figure 3 displays results related to hypotheses 1.1 and 1.2 and focuses on the reciprocal relationship between perceptions of over- and under-policing.

[FIGURE 3 HERE]

\footnotetext{
${ }^{13}$ In the same spirit, Hamaker et al. (2015) developed the random intercepts cross-lagged panel model (RI-CLPM), which explicitly distinguishes between-unit variations and within-unit change over time, thus providing estimates that are not biased by reverse causality and time-invariant unobserved heterogeneity.

${ }^{14}$ Given that some parameters were constrained to equality across waves, no observations were dropped to estimate the model. Models without full information maximum likelihood, with unconstrained parameters, and considering only respondents who took part in the study at each time period were estimated as a robustness check. Results remain virtually unaltered.
} 
First, results broadly suggest that perceptions of over- and under-policing are reciprocally related, as they are both significantly and positively associated with each other. A one-standard-deviation increase in the scores of perceived police intrusion is associated with a positive change of 0.05 standard deviations in the scores of cynicism about police protection, whereas a one-standard-deviation increase in cynicism about police protection is associated with a positive change of 0.18 standard deviations in perceived intrusion. These results, which take into account reverse causality and time-constant unobserved heterogeneity and focus on within-unit change over time, suggest that the more people expect officers to repeatedly intrude upon their lives, the more skeptic they become about the ability of legal institutions to ensure public safety - and vice-versa. Perceptions of over- and under-policing are dynamically dependent, simultaneously feeding each other, which resonates Rios's (2011) description of the overpolicingunderpolicing paradox - as predicted by hypotheses 1.1 and 1.2.

\section{[FIGURE 4 HERE]}

They also share similar, though not identical, correlates. Figure 4 displays partial results of the same two models, but now related to hypotheses 1.3 through 1.6 and focused on the social forces producing perceptions of over and under-policing. For instance, residents of area 1 - the reference group, a racially diverse neighborhood characterized by high levels of concentrated disadvantage - have similar expectations about the law and the police as residents of other structurally disadvantaged neighborhoods, such as areas 2,3 , and 4 . On the other hand, residents of wealthier and predominantly White neighborhoods, such as areas 6,7 , and 8 , tend to have significantly lower average scores of both perceptions of police intrusion and police cynicism than residents of area 1 - although, interestingly, residents of area 8 , a very wealthy neighborhood characterized by a large prevalence of gated communities, have undistinguishable scores of cynicism about police protection as members of area 1. In addition, a recent experience of being stopped by the police at gunpoint is significantly and positively associated with changes in perceptions of overpolicing (an increase of 0.41 standard deviations in the scores of perceived intrusion), but not with perceptions of under-policing. Overall, public expectations of law enforcement agents constantly interfering with the lives of neighborhood residents and widespread skepticism about their ability to ensure public safety share key predictors, most notably related to exposure to neighborhood structural conditions.

\section{7 | SECOND PART: CONSEQUENCES OF OVERPOLICING AND UNDERPOLICING}

\section{1 | Estimation strategies}

The second set of hypotheses are focused on potential consequences of perceptions of over- and underpolicing and center around judgements about the legitimacy of the police. I first assess whether cynicism about police protection and perceptions of police intrusion are associated with undermined legitimacy 
beliefs. I rely upon the 'within-between' (hybrid) model specification that combines the desirable aspects of both fixed effects and random effects econometric methods (Allison, 2009; Long, 2021). While withinperson change over time is crucial to understand the extent to which perceptions of police intrusion and police cynicism are associated with changes in legitimacy beliefs, between-person differences are also substantially interesting in this application. Similarly to Allison et al.'s (2017) dynamic panel model, the within-between model is not biased by unobserved time-constant heterogeneity, but allows for the inclusion of time-constant covariates as it simultaneously estimates separate within effects (focused on change over time) and between effects (focused on differences between individuals). Two hybrid models are estimated predicting respondents' scores of police legitimacy across the three waves: M3 includes perceptions of police intrusion and cynicism about police protection as the main independent variables and controls for race, gender, social class, and neighborhood of residence; M4 adds perceptions of procedural fairness and police stops at gunpoint, two known predictors of police legitimacy in Brazil (Jackson et al., 2022; Oliveira, 2022). The rationale for having two separate models is to assess changes in magnitude and statistical significance of any associations. Models are estimated using R's package panelr (Long, 2021).

\section{2 | Results}

Results of two within-between regression models predicting scores of police legitimacy can be found in Figure 5. Model 2A shows that, net of neighborhood of residence, social class, self-reported race, gender, and other time-invariant potential confounders, individuals who expect police officers to repeatedly intrude and interfere with people's lives and who are cynic about the ability of legal institutions to ensure public safety have lower average scores of beliefs about the legitimacy of the police (differences of - 0.23 and 0.70 points in the police legitimacy scale, respectively, for every one-standard-deviation increase in each scale). Crucially, considering three waves of data (each 18 months apart), every one-standard-deviation increase in scores of perceptions of police intrusion and cynicism about police protection is associated with negative within-respondent changes in scores of police legitimacy - changes of -0.08 and -0.36 points, respectively.

\section{[FIGURE 5 HERE]}

Results remain statistically different from zero even after controlling for key predictors of police legitimacy among São Paulo residents, such as perceptions of procedural fairness and a recent experience of being stopped by the police at gunpoint. Respondents who expect officers to be intrusive and are cynic about security and protection provision by legal institutions have substantively lower average scores of police legitimacy (differences of -0.12 and -0.19 points, respectively, for every one-standard-deviation increase in each scale). Shifts in perceptions of police intrusion and cynicism about police protection also 
remain associated with within-respondent changes in scores of police legitimacy over time: -0.06 and -0.16 points, respectively, for every one-standard-deviation in each scale.

Beliefs about the legitimacy of the police are measured as a coercive-consensual continuum (Jackson et al., 2022), so negative coefficients imply shifts towards the coercive side of the continuum. As people increase both their expectations that police officers tend to interfere with neighborhood residents' lives and their skepticism about officers' willingness to provide neighborhood residents with security and protection, they tend to start challenging legal authority's claim of power by questioning whether it is the appropriate and rightful authority and, at the same time, developing a coercive relationship with legal agents in which the law should be obeyed mainly out of fear and dismay. This set of results provide evidence in favor of hypotheses 2.1 and 2.2.

\section{8 | DISCUSSION}

Sociologists have long studied how residents of some neighborhoods experience an undue police presence that intrudes upon their lives, and yet feel unprotected by law enforcement agents who fail to provide security and protection. Ethnographic evidence of the overpolicing-underpolicing paradox in disadvantaged and ethnically diverse neighborhoods from cities in the US such as Oakland (Rios, 2011), Philadelphia (Carr et al., 2007), Chicago (Vargas, 2016; Shedd, 2015), and New York City (Haldipur, 2019) is abundant. In this study I contribute to this literature by providing a quantitative assessment of the twin harms of intrusive excess and careless neglect (Boehme et al., 2022). Crucially, I build on but depart from previous work that is concentrated on public-authority relations in the US and focus instead on one of the largest cities in the Global South. In the context of eight neighborhoods in São Paulo - where policing follows a highly militarized model, heavily armed officers are trained for war-like situations, public-police relations are marked by fear, and the idea that law enforcement agents are "just another violent gang" has cultural currency (Jackson et al., 2022) - this study relied upon three waves of longitudinal survey data to investigate the dynamics and consequences of the overpolicing-underpolicing paradox.

The empirical study has two parts. The first part is focused on the dynamics of perceptions of overand under-policing. To assess whether public expectations of repeated police intrusion and skepticism about police protection were seen as two complementary rather than antagonistic features of perceived neighborhood policing, I explored the extent to which those perceptions dynamically reproduced each other over time and shared similar correlates. Hypotheses 1.1 and 1.2 stated that perceptions of both over- and under-policing would be reciprocally related, whereas hypotheses 1.3 through 1.6 stated that both would be associated with exposure to concentrated disadvantage and to recent experiences of aggressive police stops. Using a dynamic panel model (Allison et al., 2017), I found empirical support for five of these hypotheses. 
Echoing Rios's (2011) description of the overpolicing-underpolicing paradox, I show that perceptions of police intrusion and cynicism about police protection walk side-by-side. Models M1 and M2 suggest a reciprocal relationship: the more citizens expect officers to overstep their authority and intrude upon their lives, the more cynic they grow about the ability of legal agents to ensure public safety; and viceversa - as citizens develop negative sentiments about the police and expect officers not to care about the provision of security and protection, the more they expect the police to interfere and abuse of their power. State provision of repression and protection follow a twisted dynamic. Perceptions of over- and underpolicing mutually reproduce each other over time, forming a kind of vicious cycle that characterizes policing in several underserved communities in Brazil's largest city.

In addition, perceptions of police intrusion and cynicism are produced by similar social forces. Residents of neighborhoods characterized by concentrated disadvantage and racial heterogeneity expect officers to intrude upon their lives and, at the same time, fail to ensure public safety to a greater extent than residents of more affluent and White communities. Mirroring studies on legal cynicism (Sampson \& Bartusch, 1998; Hagan et al., 2020), results of this study suggest that residents adapt to their environmental conditions and develop cultural interpretations about the functioning and viability of the law and the legal institutions (Kirk \& Papachristos, 2011; Bell, 2016; 2017). This supports hypotheses 1.3 and 1.4. Despite an apparent paradox, expectations of both over- and under-policing are informed by similar social forces.

However, exposure to aggressive policing practices seems to lead to greater expectations of overpolicing only. A recent experience of being stopped by police officers at gunpoint is associated with higher scores of perceptions of police intrusion, but not cynicism about police protection. While this result partly resonates previous work suggesting an influence of police-citizen encounters on perceptions of the law and the police (Oliveira, 2022; Tyler et al., 2014), it also indicates that perceptions of over- and underpolicing are not produced by precisely the same social forces. Among potentially several other factors beyond the scope of this paper, expectations of police intrusion are produced both by neighborhood of residence and recent exposure to abusive policing practices, whereas cynicism about police protection seems to be produced mostly in function of the structural conditions in which citizens reside. This set of results provide support for hypothesis 1.6 , but not 1.5 .

The second part of this study focused on consequences of the overpolicing-underpolicing paradox, with focus on the undermine of public beliefs about the legitimacy of the police. Models M3 and M4 suggest that public perceptions of police intrusion and cynicism about police protection are negatively associated with legitimacy beliefs, as stated by hypotheses 2.1 and 2.2. Above and beyond other legitimating norms in Brazil, such as people's expectations of procedural fairness (Jackson et al., 2022), citizens' expectations that police officers constantly interfere with their lives and are disinterested in providing security and 
protection contribute to damage public judgements about the appropriateness of legal authority's claim of power. In other words, the overpolicing-underpolicing paradox can undermine the legitimacy of legal institutions.

Why? PJT can offer some insightful explanations. The broad theoretical framework, based on the group sustains that the group value model and the group engagement model (Lind \& Tyler, 1988; Tyler \& Blader, 2000), sustains that social bonds between subjects and an authority figure are enhanced when subjects develop a sense of belonging in the superordinate group the authority figure represents. This sense of belonging can therefore be fostered by communicating to subjects that they are indeed valued members of this group. PJT then applies this logic to the legal context and suggests that when law enforcement agents exert power communicating procedural fairness, they can enhance the social bonds between the public and legal authority - mostly because fair process signals group status and value (Sunshine \& Tyler, 2003). What this study suggests is that, above and beyond signals of group status and value via procedural fairness, law enforcement agents can also send relational signals that strengthen or weaken such social bonds (Oliveira \& Jackson, 2021). When legal agents exert power in aggressive and intrusive ways and signal that they do not care about ensuring public safety, they could be sending negative identity-related messages of oppression, marginalization, and neglect - all of which signal to members of the public that they do not belong in the group legal authority represents, propelling them to lose faith in legal authority's right to rule and authority to govern.

Perceptions of over- and under-policing could therefore be legitimating norms among São Paulo residents (Rios et al., 2020). By repeatedly intruding upon the lives of people and failing to provide basic protection and security, law enforcement agents in São Paulo can contribute to weakening the social bonds between the public and legal authority, enhancing public perceptions that legal institutions operate to exclude underprivileged groups (Bell, 2017). This is a crucial contribution to the literature on legitimacy and policing. Future research should explore whether perceptions of police intrusion and cynicism about police protection also undermine legitimacy beliefs in other contexts.

When citizens are subjugated to intrusive policing practices that neglect the provision of security of protection, they start to question the legitimacy of legal institutions, developing a relationship with legal authority based on fear and coercion (Jackson et al., 2022). In a massive city in the Global South where urban violence is one of the most urgent social problems faced by residents, this study shows that public reactions to the overpolicing-underpolicing paradox can contribute to foster beliefs that legal authority is not the rightful authority - which could lead to a decrease in people's willingness to voluntarily comply with the law and cooperate with legal institutions and an increase in public tolerance of the use of violence outside the scope of the state. 


\section{1 | Limitations}

Limitations should, of course, be acknowledged. First, this study was carried out in the context of São Paulo, Brazil, which is a specific social setting in the Global South. More research about the dynamics and consequences of over- and under-policing is needed in other contexts, both in the US and elsewhere. In particular, the relationship between perceptions of perceptions of police intrusion and cynicism about police

protection and legitimacy beliefs needs to be assessed in other contexts. Second, this study only reported associations as no attempts to identify causal effects were made. All data analyzed here are observational and causal claims could not be made without unreasonably strong assumptions. Third, I did not engage in ecological analysis as only eight neighborhoods were included in the study. Ideally, future research should conduct large community surveys covering all neighborhoods within cities. More research like the Project on Human Development in Chicago Neighborhoods (Sampson, 2012) is necessary to properly assess ecological aspects of the overpolicing-underpolicing paradox, including public-authority relations in areas where criminal governance claims legitimacy (Lessing \& Willis, 2019). Fourth, measures of perceived police intrusion and cynicism about police protection used in this paper can still be improved upon. Future research should explore different survey items tapping into expectations of police interference and skepticism about the extent to which law enforcement agents care about providing members of the public with security and protection. Finally, this quantitative assessment of the dynamics and consequences of the overpolicing-underpolicing paradox focused on attitudinal measures. Future research could extend this and include administrative and behavioral data to investigate policing practices, contacts, and activities in certain neighborhoods that could reflect over- and under-policing.

\section{9 | CONCLUSIONS}

I started this study with the idea, largely documented by neighborhood ethnographies in the US, that residents of some over-policed places often experience an overwhelming presence of police that intrudes upon their lives, and yet feel neglected by the law, which is never there to protect them. This has been described as an apparent paradox: legal institutions make themselves excessively present, but at the same time are not present enough, and neighborhoods are simultaneously over- and under-policed (Rios, 2011; Carr et al., 2007). The overpolicing-underpolicing paradox is a particularly pressing issue in some Global South settings like most Brazilian cities. In an example of the increasing globalization of some policing tactics commonly adopted in the US, policing in São Paulo follows a highly militarized model, with armed officers trained for theatres of war (Oliveira, 2022). Residents of several neighborhoods suffer with epidemic levels of violent crime (Nery et al., 2019), and at the same time are fearful of law enforcement agents who often use violence to wield their power (Jackson et al., 2022). 
In this context, I made use of three waves of longitudinal survey data representative of adult residents in eight distinct neighborhoods in São Paulo between 2015 and 2019 to quantitatively assess the dynamics and consequences of the overpolicing-underpolicing paradox. Respondents perceive the overand under-policing of their communities as two complementary features, as perceptions of police intrusion and cynicism about police protection mutually reproduce each other over time and are both informed by similar social forces, such as exposure to structural disadvantage and abusive policing practices. The overpolicing-underpolicing paradox is only a paradox based on the assumption that policing ensures public safety. Once this assumption is questioned, the situation is not at all paradoxical: as largely emphasized by previous ethnographic studies, over-policed communities tend to be under-protected (Rios, 2011; Bell, 2016; 2017), and this study demonstrated quantitatively that perceived increases in coercive presence of police are associated with perceptions of less safety and protection. If the state needs to balance out its provision of oppression and protection to ensure public safety, residents of some over-policed and underprotected neighborhoods experience the worst possible scenario.

Crucially, results also revealed that perceptions of police intrusion and cynicism about police protection undermine legitimacy beliefs. This is an important contribution to the literature on policing and legitimacy. I build on and expand previous research focused on procedural justice policing by demonstrating that, above and beyond procedural injustice, intrusive and neglectful policing can also send relational messages that weaken the social bonds between members of the public and legal authority messages of oppression, marginalization, and neglect that signal group exclusion, shape groups' identities, and undermine public legitimacy beliefs (Bell, 2017; Mackenzie, 2021; Oliveira \& Jackson, 2021).

Future research should both incorporate measures of perceived police intrusion and cynicism about police protection as important (de)legitimating aspects of police conduct and explore other dimensions of police behavior that could also send identity-related messages and strengthen or weaken the social bonds between legal authority and members of the public. In addition, it is imperative that future research investigates public-authority relations in understudied Global South settings, where militarized policing tactics centered around increased coercive presence commonly adopted in the US are being increasingly adopted.

\section{REFERENCES}

Adorno, Sergio. 2013. "Democracy in Progress in Contemporary Brazil: Corruption, Organized Crime, Violence and New Paths to the Rule of Law." International Journal of Criminology and Sociology 2: 409-425.

Allison, Paul. 2009. Fixed Effects Regression Models. SAGE Publications

Allison, Paul, Richard Williams, and Enrique Mora-Benito. 2017. "Maximum likelihood for cross-lagged panel models with fixed effects." Socius 3. 
Bailey, Stanley, Mara Loveman, and Jeronimo Muniz. 2013. "Measures of 'Race' and the Analysis of Racial Inequality in Brazil." Social Science Research 42 (1): 106-19.

Beetham, David. 2013. The Legitimation of Power. Macmillan International Higher Education.

Bell, Monica C. 2016. "Situational Trust: How Disadvantaged Mothers Reconceive Legal Cynicism." Law \& Society Review 50 (2): 314-47.

Bell, Monica. 2017. Police Reform and the Dismantling of Legal Estrangement." The Yale Law Journal: 20542150.

Biderman, Ciro, João MP De Mello, Renato S De Lima, and Alexandre Schneider. 2018. "Pax Monopolista and Crime: The Case of the Emergence of the Primeiro Comando da Capital in São Paulo." Journal of Quantitative Criminology 35: 573-605.

Black, Donald. 1983. "Crime as Social Control.” American Sociological Review 48 (1): 34-45.

Boehme, Hunter M., Deana Cann, and Deena A. Isom. 2022. "Citizens' Perceptions of Over- and UnderPolicing: A Look at Race, Ethnicity, and Community Characteristics." Crime \& Delinquency 68 (1): 123154.

Caldeira, Teresa PR. 2002. "The Paradox of Police Violence in Democratic Brazil.” Ethnography 3 (3): 235 -63.

Campeau, Holly, Ron Levi, and Todd Foglesong. 2020. "Policing, Recognition, and the Bind of Legal Cynicism." Social Problems. https://doi.org/10.1093/socpro/spaa017

Carr, Patrick J, Laura Napolitano, and Jessica Keating. 2007. "We Never Call the Cops and Here Is Why: A Qualitative Examination of Legal Cynicism in Three Philadelphia Neighborhoods." Criminology 45 (2): 445-80.

Cerqueira, Daniel, Samira Bueno, Paloma Alves, Renato Sergio de Lima, et al. 2020. Atlas da violencia. IPEA.

Coicaud, Jean-Marc. 2002. Legitimacy and Politics: A Contribution to the Study of Political Right and Political Responsibility. Cambridge University Press.

Dias, Camila Nunes, and Sacha Darke. 2016. "From Dispersed to Monopolized Violence: Expansion and Consolidation of the Primeiro Comando Da Capital's Hegemony in São Paulo's Prisons." Crime, Law and Social Change 65 (3): 213-25.

Fagan, Jeffrey, and Tom Tyler. 2005. "Legal Socialization of Children and Adolescents." Social Justice Research 18 (3): 217-41.

Fagan, Jeffrey. Anthony Braga, Rod Brunson, and April Pattavina. 2016. "Street and Stares: Street Stops, Surveillance, and Race in the New Policing." Fordham Urb. LJ. 43: 539.

Feltran, Gabriel. 2020. Entangled City: Crime as Urban Fabric in Sao Paulo. Manchester University Press.

Fine, Adam, and Elizabeth Cauffman. 2015. "Race and Justice System Attitude Formation During the Transition to Adulthood." Journal of Developmental and Life-Course Criminology 1 (4): 325-49.

Gau, Jacinta M. 2015. "Procedural Justice, Police Legitimacy, and Legal Cynicism: A Test for Mediation Effects." Police Practice and Research 16 (5): 402-15.

Gonzales, Yanilda M. 2017. "'What citizens can see of the state': Police and the construction of democratic citizenship in Latin America." Theoretical Criminology 21 (4): 494-511.

Gonzales, Yanilda M. 2020. Authoritarian police in democracy: Contested security in Latin America. Cambridge University Press.

Hagan, John, Bill McCarthy, and Daniel Herda. 2020. "What the Study of Legal Cynicism and Crime Can Tell Us About Reliability, Validity, and Versatility in Law and Social Science Research." Annual Review of Law and Social Science 16: 1-20.

Hagan, John, Bill McCarthy, Daniel Herda, and Andrea Cann Chandrasekher. 2018. "Dual-Process Theory of Racial Isolation, Legal Cynicism, and Reported Crime." Proceedings of the National Academy of Sciences 115 (28): 7190-9.

Hagan, John, Joshua Kaiser, and Anna Hanson. 2016. "The theory of legal cynicism and Sunni insurgent violence in post-invasion Iraq." American Sociological Review 81 (2): 316-346.

Haldipur, Jan. 2019. No Place on the Corner: The Costs of Aggressive Policing. NYU Press.

Hamaker, Ellen L, Rebecca M Kuiper, and Raoul PPP Grasman. 2015. "A Critique of the Cross-Lagged Panel Model." Psychological Methods 20 (1): 102.

Huq, Aziz Z., Jonathan Jackson, and Rick Trinkner. 2017. "Legitimating Practices: Revisiting the Predicates of Police Legitimacy." The British Journal of Criminology 57 (5): 1101-1122. 
Jackson, Jonathan. 2018. "Norms, Normativity, and the Legitimacy of Justice Institutions: International Perspectives." Annual Review of Law and Social Science 14: 145-165.

Jackson, Jonathan, Ben Bradford, Mike Hough, Andy Myhill, Paul Quinton, and Tom R. Tyler. 2012. "Why do people comply with the law? Legitimacy and the influence of legal institutions." The British Journal of Criminology 52 (6): 1051-1071.

Jackson, Jonathan, Aziz Z Huq, Ben Bradford, and Tom R Tyler. 2013. "Monopolizing Force? Police Legitimacy and Public Attitudes Toward the Acceptability of Violence." Psychology, Public Policy, and Law 19 (4): 479.

Jackson, Jonathan, and Ben Bradford. 2019. "Blurring the Distinction Between Empirical and Normative Legitimacy? A Methodological Commentary on 'Police Legitimacy and Citizen Cooperation in China'." Asian Journal of Criminology 14 (4): 265-289.

Jackson, Jonathan, Krisztián Pósch, Thiago R. Oliveira, Ben Bradford, Silvia M Mendes, Ariadne Lima Natal, and André Zanetic. Forthcoming, 2022. "Fear and Legitimacy in São Paulo, Brazil: Police-Citizen Relations in a High Violence, High Fear City." Law \& Society Review.

Kane, Robert J. 2005. "Compromised Police Legitimacy As a Predictor of Violent Crime in Structurally Disadvantaged Communities." Criminology 43 (2): 469-498.

Katsikatsou, Myrsini, Irini Moustaki, Fan Yang-Wallentin, and Karl Joreskog. 2012. "Pairwise likelihood estimation for factor analysis models with ordinal data." Computational Statistics \& Data Analysis 56 (12): 4243-4258.

Kirk, David. 2016. "Prisoner Reentry and the Reproduction of Legal Cynicism.” Social Problems 63 (2): $222-$ 43.

Kirk, David, and Mauri Matsuda. 2011. "Legal Cynicism, Collective Efficacy, and the Ecology of Arrest." Criminology 49 (2): 443-72.

Kirk, David, and Andrew Papachristos. 2011. "Cultural Mechanisms and the Persistence of Neighborhood Violence." American Journal of Sociology 116 (4): 1190-1233.

Kubrin, Charis E., and Ronald Weitzer. 2003. "Retaliatory Homicide: Concentrated Disadvantage and Neighborhood Culture." Social Problems 50 (2): 158-180.

Leszczensky, Lars and Tobias Wolbring. 2019. "How to deal with reverse causality using panel data? Recommendations for researchers based on a simulation study." Sociological Methods \& Research 51 (2): $837-865$.

Lessing, Benjamin, and Graham Denyer Willis. 2019. "Legitimacy in Criminal Governance: Managing a Drug Empire from Behind Bars." American Political Science Review 113 (2): 584-606.

Lind, E. Allan, and Tom R. Tyler. 1988. The Social Psychology of Procedural Justice. Springer Science \& Business Media.

Long, Jacob. 2021. An introduction to the panelr package. Available at https://panelr.jacoblong.com/articles/wbm.html

Mackenzie, Catriona. 2021. "Procedural Justice, Relational Equality, and Self-Respect." In: Meyerson, Denise, Catriona Mackenzie, and Therese MacDermott. Procedural Justice and Relational Theory: Empirical, Philosophical, and Legal Perspectives. Routledge.

Manso, Bruno Paes, and Camila Nunes Dias. 2018. A Guerra: A Ascensão do PCC e o Mundo do Crime no Brasil. Editora Todavia SA.

Mariano, Benedito D. 2018. Pesquisa sobre o uso da força letal por policiais de São Paulo e vitimização policial em 2017. São Paulo, Brazil: Ouvidoria das Polícias do Estado de São Paulo.

Marques, Eduardo. 2016. São Paulo in the Twenty-First Century: Spaces, Heterogeneities, Inequalities. Routledge.

Mazerolle, Lorraine, Sarah Bennett, Jacqueline Davis, Elise Sargeant, and Matthew Manning. 2013. "Procedural justice and police legitimacy: A systematic review of the research evidence." Journal of Experimental Criminology 9 (3): 245-274.

McCarthy, Bill, John Hagan, and Daniel Herda. 2020. "Neighborhood Climates of Legal Cynicism and Complaints about Abuse of Police Power." Criminology 58 (3): 510-536.

Morgan, Stephen, and Christopher Winship. 2015. Counterfactuals and Causal Inference: Methods and Principles for Social Research. New York: Cambridge University Press. 
Nery, Marcelo Batista, Maria Fernanda Tourinho Peres, Narcy Cardia, Diego Vicentin, and Sergio Adorno. 2012. "Regimes Espaciais: Dinâmicas dos Homicídios Dolosos na Cidade de São Paulo entre 2000 e 2008." Rev Panam Salud Public 32 (6): 405-412.

Nery, Marcelo Batista, Altay Alves Lino de Souza, and Sergio Adorno. 2019. "Os Padrões UrbanoDemográficos da Capital Paulista." Estudos Avançados 33 (97): 5-36.

Nivette, Amy E, Manuel Eisner, and Denis Ribeaud. 2019. "Evaluating the Shared and Unique Predictors of Legal Cynicism and Police Legitimacy from Adolescence into Early Adulthood." Criminology. https://doi.org/10.1111/1745-9125.12230

Oliveira, Thiago R. 2022. "Aggressive policing and undermined legitimacy: assessing the impact of police stops at gunpoint on perceptions of police in Sao Paulo, Brazil." Journal of Experimental Criminology. https://doi.org/10.1007/s11292-022-09527-9

Oliveira, Thiago R, Jonathan Jackson, Kristina Murphy, and Ben Bradford. 2021. "Are Trustworthiness and Legitimacy 'Hard to Win and Easy to Lose'? A Longitudinal Test of the Asymmetry Thesis of PoliceCitizen Contact." Journal of Quantitative Criminology 47 (4): 1003-1045. https://doi.org/10.1007/s10940-020-09478-2

Oliveira, Thiago R., André R. Oliveira, and Sergio Adorno. 2019. "Legitimidade Policial: um Modelo de Mensuração." Revista Brasileira de Ciências Sociais 34 (100).

Oliveira, Thiago R., Andre Zanetic, and Ariadne Natal. 2020. "Preditores e Impactos da Legitimidade Policial: Testando a Teoria da Justeza Procedimental em São Paulo." Dados - Revista de Ciências Sociais 63 (1).

Oliveira, Thiago R., and Jonathan Jackson. 2021. "Legitimacy, Trust and Legal Cynicism: A Review of Concepts." Tempo Social 33(3): 113-145.

Oliveira, Thiago R., Jonathan Jackson, Renan Theodoro, Debora Piccirillo, and Rick Trinkner. 2022. "Socialization through violence: Exposure to neighborhood and police violence and the development of legitimacy beliefs among adolescents in Sao Paulo." Working paper. Available at https://osf.io/preprints/socarxiv/v3h97/

Omori, Marisa, Rachel Lautenschlager, and Justin Stoler. 2022. "Organizational Practice and Neighborhood Context of Racial Inequality in Police Use-of-Force." Social Problems. https://doi.org/10.1093/socpro/spac031

Papachristos, Andrew, Tracey Meares, and Jeffrey Fagan. 2012. "Why do criminals obey the law? The influence of legitimacy and social networks on active gun offenders." Journal of Criminal Law and Criminology 102.

Pinc, Tânia. 2006. O uso da força não-letal pela polícia nos encontros com o público. $\mathrm{PhD}$ thesis, University of São Paulo.

Reisig, Michael D, Scott E Wolfe, and Kristy Holtfreter. 2011. "Legal Cynicism, Legitimacy, and Criminal Offending: The Nonconfounding Effect of Low Self-Control." Criminal Justice and Behavior 38 (12): 1265-79.

Rios, Victor M. 2011. Punished: Policing the Lives of Black and Latino Boys. NYU Press.

Rios, Victor M, Greg Prieto, and Jonathan M Ibarra. 2020. "Mano Suave-Mano Dura: Legitimacy Policing and Latino Stop-and-Frisk." American Sociological Review 85 (1): 58-75.

Sampson, Robert J. 2012. Great American City: Chicago and the Enduring Neighborhood Effect. University of Chicago Press.

Sampson, Robert J., Stephen W. Raudenbush, and Felton Earls. 1997. "Neighborhoods and Violent Crime: A Multilevel Study of Collective Efficacy." Science 277(5328): 918-924.

Sampson, Robert J, and Dawn Jeglum Bartusch. 1998. "Legal Cynicism and (Subcultural) Tolerance of Deviance: The Neighborhood Context of Racial Difference." Law \& Society Review 32: 777.

Sampson, Robert J., and William Julius Wilson. 1995. Toward a Theory of Race, Crime, and Urban Inequality. Standford University Press.

Sharkey, Patrick. 2018. Uneasy Peace: The Great Crime Decline, the Renewal of City Life, and the Next War on Violence. WW Norton \& Company.

Shedd, Carla. 2015. Unequal City: Race, School, and Perceptions of Injustice. Russell Sage Foundation.

Sinhoretto, Jacqueline, Maria Carolina Schlittler, and Giane Silvestre. 2016. "Juventude e Violência Policial no Município de São Paulo.” Revista Brasileira de Segurança Pública 10: 10-35. 
Stuart, Forrest. 2016. Down, Out, and Under Arrest: Policing and Everyday Life in Skid Row. University of Chicago Press.

Sunshine, Jason, and Tom Tyler. 2003. "The Role of Procedural Justice and Legitimacy in Public Support for Policing." Law and Society Review 37 (3): 513-48.

Suss, Joel, and Thiago R. Oliveira. 2022. "Economic Inequality and the Spatial Distribution of Stop and Search: Evidence from London.” The British Journal of Criminology. https://doi.org/10.1093/bjc/azac069

Tankebe, Justice. 2009 "Self-Help, Policing, and Procedural Justice: Ghanaian Vigilantism and the Rule of Law." Law and Society Review 43 (2): 245-270/

Terrill, William, and Michael D. Reisig. 2003. "Neighborhood Context and Police Use of Force." Journal of Research in Crime and Delinquency 40 (3): 291-321.

Trinkner, Rick. 2019. "Clarifying the Contours of the Police Legitimacy Measurement Debate: A Response to Cao and Graham." Asian Journal of Criminology 14 (4): 309-35.

Trinkner, Rick, Jonathan Jackson, and Tom R Tyler. 2018. "Bounded Authority: Expanding 'Appropriate' Police Behavior Beyond Procedural Justice." Law and Human Behavior 42 (3): 280.

Trinkner, Rick, Herbert Rodrigues, Debora Piccirillo, Faith Gifford, and Aline Gomes. "Legal socialisation in Brazil: examining the generalisability of the procedural justice model." International Journal of Comparative and Applied Criminal Justice 44 (2): 7-27.

Tyler, Tom R. 2006. Why People Obey the Law. Princeton University Press.

Tyler, Tom R., Jeffrey Fagan, and Amanda Geller. 2014. "Street Stops and Police Legitimacy: Teachable Moments in Young Urban Men's Legal Socialization.” Journal of Empirical Legal Studies 11 (4): 75185.

Tyler, Tom R., and Yuen J. Huo. 2003. Trust in the Law: Encouraging Public Cooperation with the Police and Courts. Russell Sage Foundation.

Tyler, Tom R, and Steven L Blader. 2003. "The Group Engagement Model: Procedural Justice, Social Identity, and Cooperative Behavior." Personality and Social Psychology Review 7 (4): 349-61.

Tyler, Tom R, Jonathan Jackson, and Avital Mentovich. 2015. "The Consequences of Being an Object of Suspicion: Potential Pitfalls of Proactive Police Contact.” Journal of Empirical Legal Studies 12 (4): 60236.

Tyler, Tom, and Rick Trinkner. 2017. Why Children Follow Rules: Legal Socialization and the Development of Legitimacy. New York: Oxford University Press.

Tyler, Tom R., and Jonathan Jackson. 2014. "Popular Legitimacy and the Exercise of Legal Authority: Motivating Compliance, Cooperation, and Engagement." Psychology, Public Policy, and Law 20 (1): 7895.

VanderWeele, Tyler. 2015. Explanation in Causal Inference: Methods for Mediation and Interaction. Oxford University Press.

Vargas, Robert. 2016. Wounded City: Violent Turf Wars in a Chicago Barrio. Oxford University Press.

Willis, Graham Denyer. 2009. "Deadly Symbiosis? The PCC, the State, and the Institutionalization of Violence in São Paulo, Brazil." In Youth Violence in Latin America, 167-81. Springer.

Willis, Graham Denver. 2015. The killing consensus: police, organized crime, and the regulation of life and death in urban Brazil. University of California Press. 
Exposure to
police conduct $\stackrel{\text { Teachable moments }}{\stackrel{\text { and cultural experiences }}{\longrightarrow}}$

(e.g., public-police interac-

tions, neighborhood expe-

riences, episodes of police

violence, cumulative life-

course exposures to police

misconduct, etc.)

\section{Expectations}

about how officers

tend to behave

$\underset{\text { to exert power appropriately }}{\stackrel{\text { Officers are trustworthy }}{\longrightarrow}}$

Beliefs about the

legitimacy of legal institutions

(task-specific assessments

of police behavior, e.g., per-

ceptions of police procedu-

ral fairness, police intru-

sion, cynicism about police

protection, etc.) (e.g., normative alignment

with values legal institu-

tions represent and duty to

obey the law and directives

from legal agents) $\underset{\text { the rightful authority }}{\stackrel{\text { Legal authority is }}{\longrightarrow}}$

Behavioral outcomes

(e.g., voluntary compliance with the law, willingness

to cooperate with legal authorities, lack of tolerance

of violence, etc.)

Fig. 1. Theoretical framework outlining the theorized causes and consequences of public beliefs about the legitimacy of legal institutions 


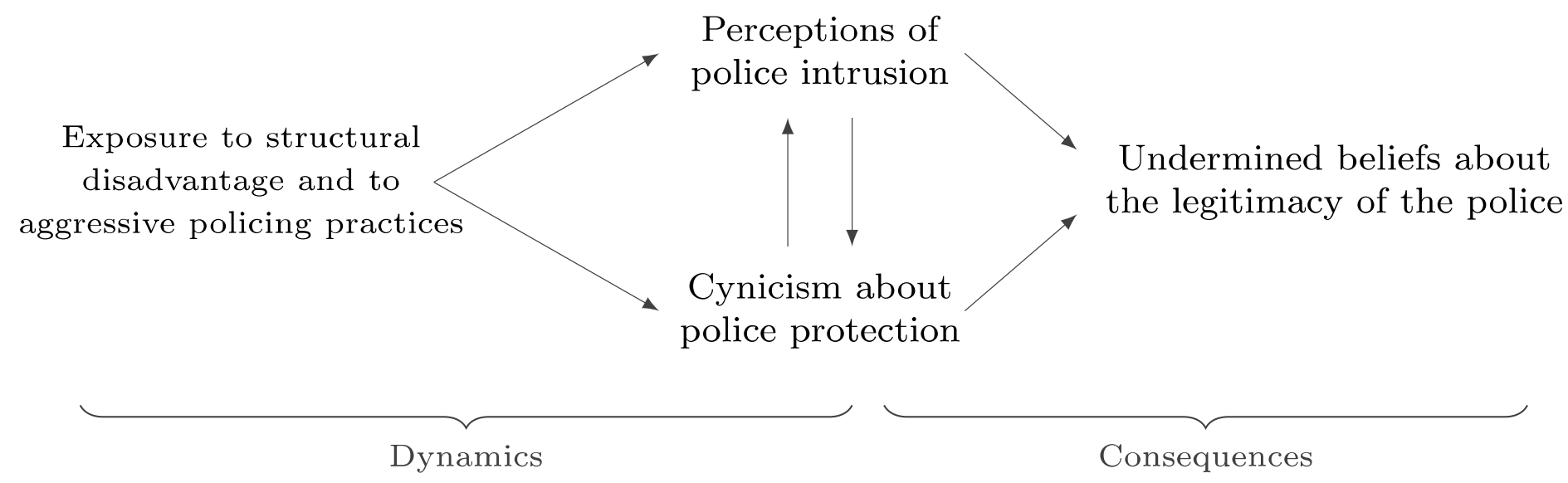

Fig. 2. A conceptual model of the dynamics and consequences of the overpolicing-underpolicing paradox 


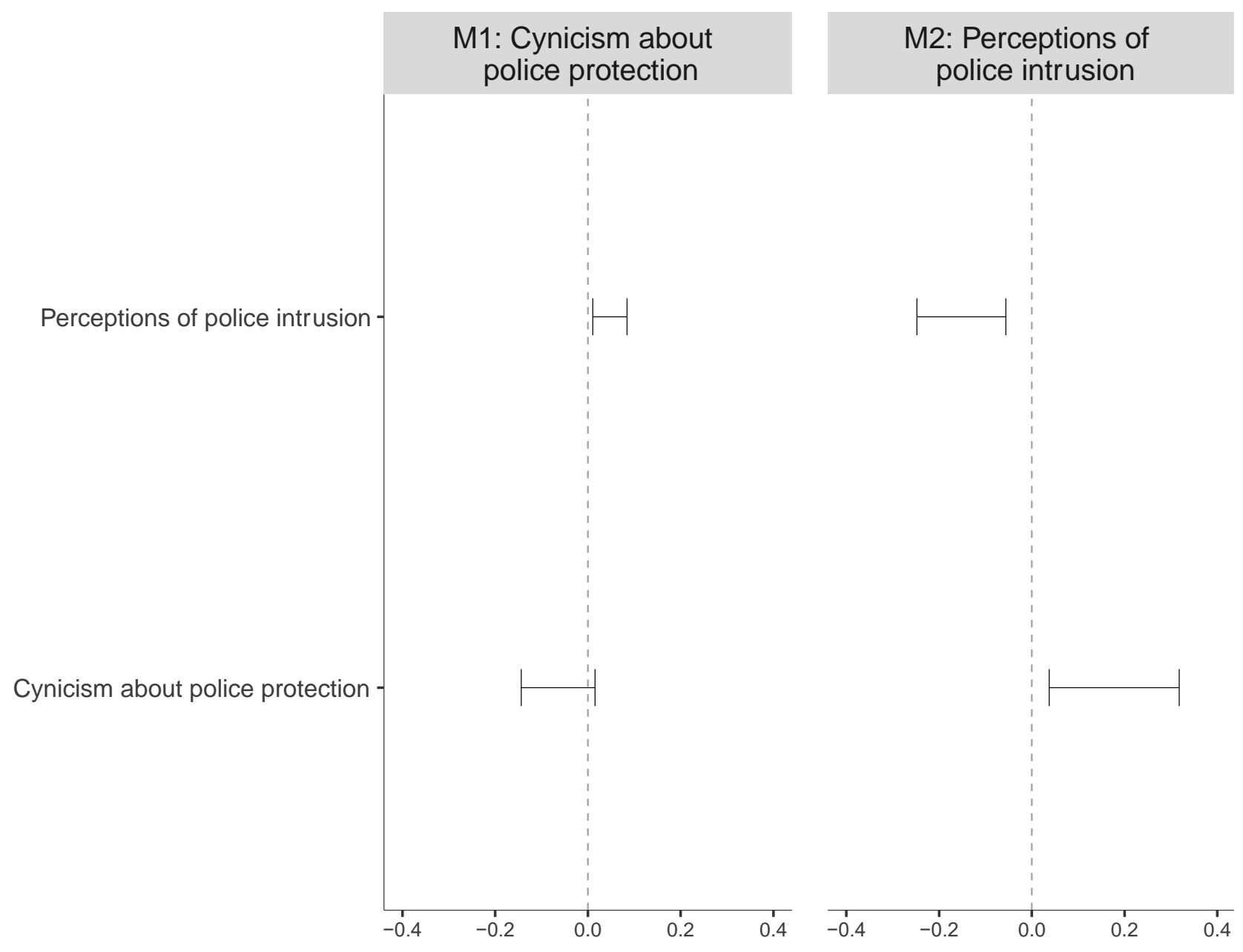

Two ML-SEMs estimating the effects of perceptions of police intr usion on cynicism about police protection (M1) and the effects of cynicism about police protection on perceptions of police intr usion (M2).

Fully standardized coefficients and 95\% confidence inter vals reported. $n=1200$ for both models (using FIML).

Fig. 3. ML-SEMs exploring the reciprocal relationship between cynicism about police protection and perceptions of police intrusion 


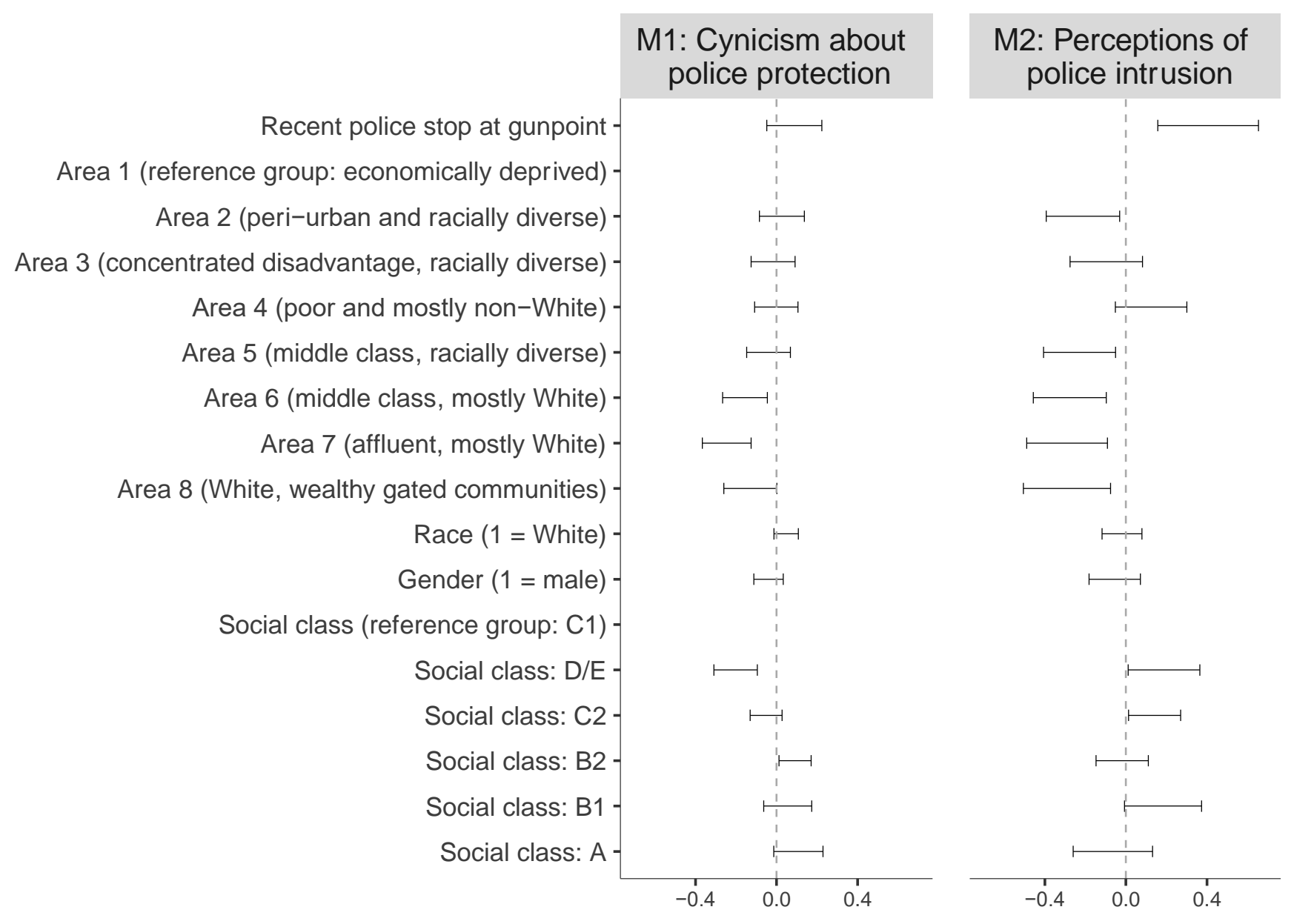

Two ML-SEMs estimating the effects of perceptions of police intr usion on cynicism about police protection (M1) and the effects of cynicism about police protection on perceptions of police intr usion (M2).

Fully standardized coefficients and $95 \%$ confidence inter vals reported. $n=1200$ for both models (using FIML).

Fig. 4. Two ML-SEMs exploring the correlates of cynicism about police protection and perceptions of police intrusion 

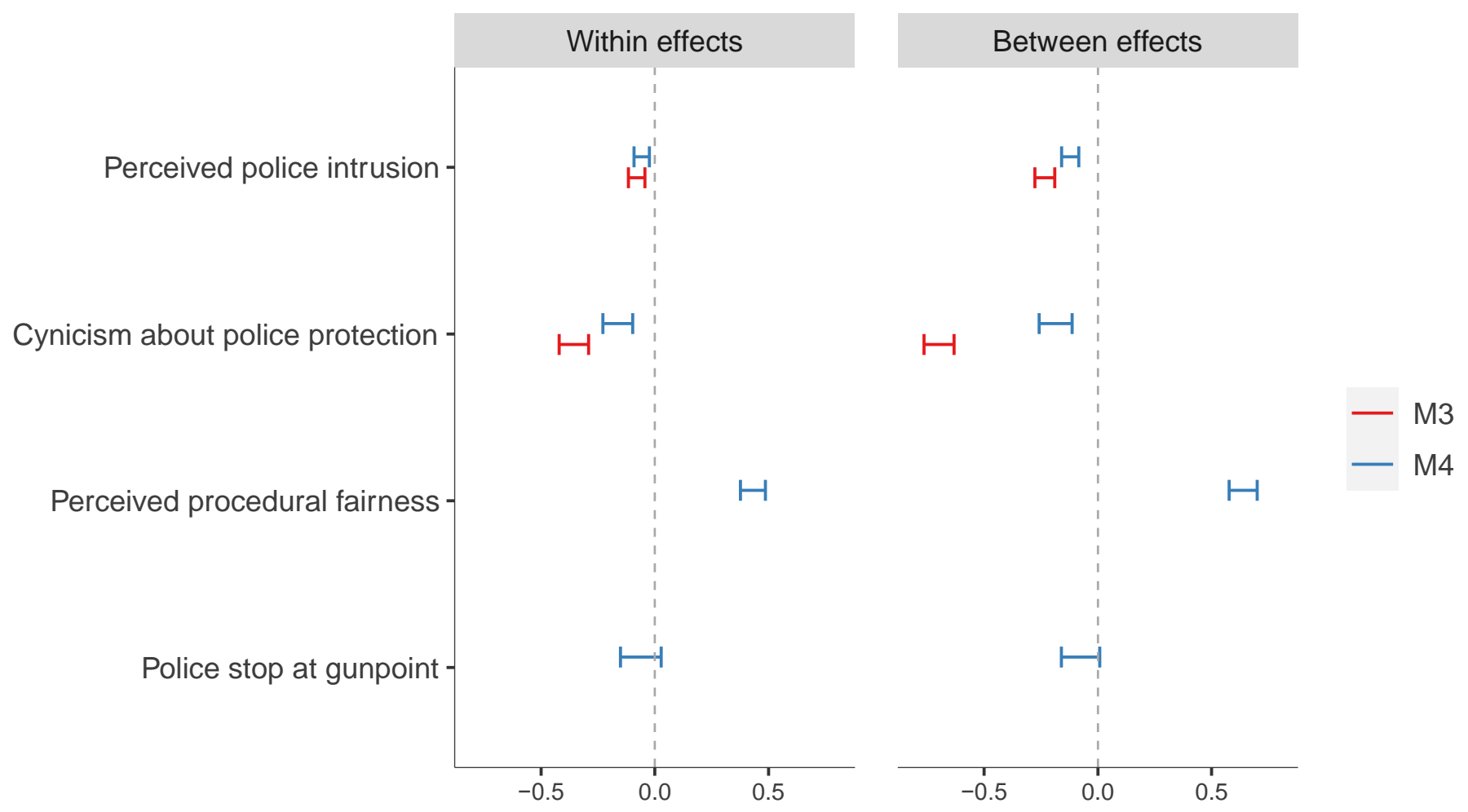

Within-between (hybrid) regression models estimated using R's package panelr . Estimated coefficients and $95 \%$ confidence inter vals reported. Within-individual and betw een-individual effects reported.

Both models control for race, sex, social class, and neighborhood of residence. Model 4 includes perceptions of procedur al fairness and a recent police stop as control v ariables.

$$
\begin{aligned}
& N=2929 \text { and } n=975 \text { for Model } 2 A . \\
& N=2923 \text { and } n=969 \text { for Model } 2 B .
\end{aligned}
$$

Fig. 5. Two within-between (hybrid) regression models exploring the association between cynicism about police protection and perceptions of police intrusion and beliefs about the legitimacy of the police 
TABLE 1 Average response of all survey indicators by wave

\begin{tabular}{|c|c|c|c|c|c|}
\hline Construct & Survey items & Wave 1 & Wave 2 & Wave 3 & $\begin{array}{c}\text { Factor/trait } \\
\text { loading }\end{array}$ \\
\hline \multirow{2}{*}{$\begin{array}{l}\text { Perceived police } \\
\quad \text { intrusion }\end{array}$} & $\begin{array}{l}\text { - Police officers act as if they were above the law in my } \\
\text { neighborhood }\end{array}$ & 3.44 & 3.42 & 3.33 & 4.35 \\
\hline & $\begin{array}{l}\text { Police officers follow and harass people in my } \\
\text { neighborhood }\end{array}$ & 2.84 & 2.86 & 2.74 & 1.44 \\
\hline \multirow{3}{*}{$\begin{array}{l}\text { Cynicism about } \\
\text { police protection }\end{array}$} & - Laws protect me (reverse coded) & 3.48 & 3.27 & 3.11 & 0.68 \\
\hline & $\begin{array}{l}\text { - Police in my neighborhood ensure my safety (reverse } \\
\text { coded) }\end{array}$ & 3.01 & 3.11 & 3.04 & 1.00 \\
\hline & $\begin{array}{l}\text { - The police are doing a good job in relation to keeping } \\
\text { the streets of my neighborhood peaceful (reverse } \\
\text { coded) }\end{array}$ & 2.96 & 3.05 & 2.96 & 0.93 \\
\hline \multirow{7}{*}{$\begin{array}{c}\text { Police } \\
\text { legitimacy }\end{array}$} & $\begin{array}{l}\text { - The police act in accordance with what you believe is } \\
\text { right and wrong }\end{array}$ & 3.17 & 3.08 & 3.14 & 1.506 \\
\hline & - People are afraid of the police & 3.87 & 3.44 & 3.33 & -0.601 \\
\hline & $\begin{array}{l}\text { - Do you think you should obey the police when you } \\
\text { believe they are wrong? }(1=\text { yes })\end{array}$ & 0.69 & 0.74 & 0.73 & \\
\hline & $\begin{array}{l}\text { Why do you think you (should/should not) obey the } \\
\text { police even when you believe they are wrong? } \\
\text { - (Yes) Normatively grounded duty to obey }\end{array}$ & 0.31 & 0.33 & 0.34 & 0.511 \\
\hline & - (Yes) Coercive obligation to obey & 0.40 & 0.41 & 0.41 & -- \\
\hline & - $\quad$ (No) Disobedient protest & 0.08 & 0.09 & 0.07 & 0.083 \\
\hline & - $\quad$ (No) Rejection of authority & 0.21 & 0.17 & 0.19 & -0.159 \\
\hline \multirow{4}{*}{$\begin{array}{l}\text { Perceived } \\
\text { procedural } \\
\text { fairness }\end{array}$} & e police in your neighborhood: & & & & \\
\hline & - Explain clearly why they pull someone over & 2.91 & 2.83 & 2.89 & 1.00 \\
\hline & - Make impartial and just decisions & 3.15 & 3.12 & 3.17 & 1.11 \\
\hline & $\begin{array}{l}\text { - Pay attention to the information people provide them } \\
\text { with }\end{array}$ & 3.32 & 3.32 & 3.30 & 1.18 \\
\hline
\end{tabular}




\begin{tabular}{|c|c|c|c|c|c|}
\hline & - Treat people with respect & 3.67 & 3.69 & 3.70 & 1.09 \\
\hline -- & Police stop $(0=$ no recent police stop $)$ & 0.38 & 0.24 & 0.24 & -- \\
\hline -- & $\begin{array}{l}\text { Police stop at gunpoint }(0=\text { no recent police stop or recent } \\
\text { police stop with no guns })\end{array}$ & 0.17 & 0.12 & 0.12 & -- \\
\hline -- & Race $(1=$ white $)$ & 0.57 & 0.56 & 0.56 & -- \\
\hline -- & Gender $(1=$ male $)$ & 0.47 & 0.46 & 0.46 & -- \\
\hline -- & Social class: A & 0.09 & 0.09 & 0.08 & -- \\
\hline -- & Social class: B2 & 0.08 & 0.08 & 0.09 & -- \\
\hline-- & Social class: B1 & 0.24 & 0.23 & 0.24 & -- \\
\hline-- & Social class: C2 & 0.25 & 0.27 & 0.26 & -- \\
\hline -- & Social class: C1 & 0.24 & 0.24 & 0.24 & -- \\
\hline-- & Social class: D/E & 0.10 & 0.09 & 0.09 & -- \\
\hline
\end{tabular}

Note. Estimated means/proportions reported. Unless stated otherwise, all survey indicators were measured using a five-point Likert scale. 
TABLE 2 Characteristics of the eight neighborhoods

\begin{tabular}{|c|c|c|c|c|c|c|c|c|}
\hline Characteristics & $\begin{array}{c}\text { Area 1 } \\
\text { (economically } \\
\text { precarious, } \\
\text { racially diverse) }\end{array}$ & $\begin{array}{c}\text { Area } 2 \\
\text { (remote and } \\
\text { peri-urban, } \\
\text { racially diverse) }\end{array}$ & $\begin{array}{c}\text { Area } 3 \\
\text { (structurally } \\
\text { disadvantaged, } \\
\text { racially diverse) }\end{array}$ & $\begin{array}{c}\text { Area } 4 \\
\text { (poor, } \\
\text { predominantly } \\
\text { non-white) }\end{array}$ & $\begin{array}{c}\text { Area } 5 \\
\text { (middle class, } \\
\text { racially diverse) }\end{array}$ & $\begin{array}{c}\text { Area } 6 \\
\text { (middle class, } \\
\text { predominantly } \\
\text { white) }\end{array}$ & $\begin{array}{c}\text { Area } 7 \\
\text { (affluent, } \\
\text { predominantly } \\
\text { white) }\end{array}$ & $\begin{array}{c}\text { Area } 8 \\
\text { (wealthy gated } \\
\text { communities, } \\
\text { predominantly } \\
\text { white) }\end{array}$ \\
\hline Criminal patterns $\perp$ & $\begin{array}{l}\text { High homicide } \\
\text { rates }\end{array}$ & $\begin{array}{l}\text { High homicide } \\
\text { rates }\end{array}$ & $\begin{array}{l}\text { High homicide } \\
\text { rates }\end{array}$ & $\begin{array}{l}\text { High homicide } \\
\text { rates }\end{array}$ & $\begin{array}{l}\text { Low homicide } \\
\text { rates }\end{array}$ & $\begin{array}{l}\text { Low homicide } \\
\text { rates }\end{array}$ & $\begin{array}{l}\text { No homicides } \\
\text { registered } \\
\text { between } 2000 \\
\text { and } 2010\end{array}$ & $\begin{array}{l}\text { Low homicide } \\
\text { rates }\end{array}$ \\
\hline Population & 26,068 & 15,361 & 41,371 & 14,862 & 21,740 & 29,230 & 38,721 & 23,286 \\
\hline $\begin{array}{l}\text { Proportion of youth (16-24 } \\
\text { year-olds) [0;1]* }\end{array}$ & 0.25 & 0.26 & 0.24 & 0.21 & 0.18 & 0.17 & 0.13 & 0.20 \\
\hline $\begin{array}{l}\text { Proportion of whites } \\
\qquad[0 ; 1]^{*}\end{array}$ & 0.49 & 0.45 & 0.43 & 0.31 & 0.51 & 0.65 & 0.80 & 0.87 \\
\hline $\begin{array}{l}\text { Average social class } \\
\text { [1 (A); } 6(\mathrm{E})]^{*}\end{array}$ & 4.31 & 4.04 & 4.46 & 4.43 & 4.1 & 3.79 & 2.8 & 2.1 \\
\hline $\begin{array}{c}\text { Proportion of police stops } \\
{[0 ; 1](0=\text { no recent police }} \\
\text { stop })^{*}\end{array}$ & 0.35 & 0.43 & 0.41 & 0.42 & 0.37 & 0.40 & 0.34 & 0.33 \\
\hline $\begin{array}{l}\text { Proportion of police stops at } \\
\text { gunpoint }[0 ; 1] \\
\left(0=\begin{array}{c}\text { recent police not at } \\
\text { gunpoint })^{*}\end{array}\right.\end{array}$ & 0.42 & 0.53 & 0.47 & 0.65 & 0.50 & 0.40 & 0.28 & 0.22 \\
\hline $\begin{array}{l}\text { Average scores of perceived } \\
\text { police intrusion } \\
{[-1.53 ;+1.19]^{*}}\end{array}$ & 0.07 & 0.06 & 0.08 & 0.23 & -0.01 & -0.08 & -0.18 & -0.20 \\
\hline $\begin{array}{c}\text { Average scores of cynicism } \\
\text { about police protection } \\
{[-1.21 ;+1.36]^{*}}\end{array}$ & 0.11 & 0.06 & 0.05 & 0.02 & -0.01 & -0.09 & -0.10 & 0.05 \\
\hline
\end{tabular}

Note. * Sample means of variables at first time point reported. Variable ranges shown in square brackets. $\perp$ Criminal patterns are described according to Nery et al. (2012), who classified census tracts in São Paulo based on their own and their neighboring tracts' homicide rates. 'High homicide rates,' in this case, refer to areas with a higher homicide rate than both the average for the city and their neighbors' rates - often consisting of at least 15 homicides per 100,000 habitants. 


\section{APPENDIX: MEASUREMENT MODELS}

\section{A.1 | MEASURING POLICE LEGITIMACY}

Following Jackson et al. (2022), police legitimacy is measured as a coercive-consensual continuum, which is measured by survey items tapping into the ideas of normative alignment with the police, fear of the police, and duty to obey the police. To measure normative alignment, respondents were asked about the extent to which they agreed that "the police act in accordance with what you believe is right or wrong." To measure fear of the police, respondents were asked about the extent to which they agreed that "people are afraid of the police." Both items were measured using a five-point likert scale ranging from (1) never to (5) always. Exact wording can be found in Table A1. All variables were measured in Portuguese and translated into English by me - for the sake of transparency, both the original and the translated versions of all survey items are displayed.

\section{[TABLE A1 ABOUT HERE]}

To measure duty to obey, respondents were asked whether they thought they "should obey the police even when you believe they are wrong" (a binary indicator with 'yes' or 'no' as response alternatives). They were then subsequently asked why they thought they "(should/should not) obey the police even when you believe they are wrong," an open-ended follow-up question. Those open-ended responses were classified based on a supervised machine learning text classification model using a support vector machine model algorithm (Hastie, Tibshirani, \& Friedman, 2009). On previous work, Jackson et al. (2022) and Oliveira et al. (2020) have analyzed the exact same open-ended responses for a different survey ${ }^{15}$ and, based on a thematic analysis involving multiple researchers, proposed four categories of duty to obey the police: those who said they should obey the police did so because of a normatively grounded duty to obey or based on a coercive obligation, whereas those who said they should not did so as a form of rejection of authority or as a type of disobedient protest.

After removing punctuation and stop words, turning everything into lowercase, and stemming inflected words to their base forms using the R package quanteda (Benoit et al., 2018), I first focused only on those who responded 'yes' to the first question (i.e., differentiating between normative and coercive obligation to obey) and used this previous classification to train a machine learning classification model; then I did the same for those who responded 'no' (i.e., differentiating between rejection of authority and disobedient protest). With a cross validation rate of $87 \%$ for the first and $80 \%$

15 Two surveys were fielded using the same questionnaire: a 2015 representative survey of the adult population residing in the city of São Paulo and a three-wave panel survey representative of the adult population residing in eight neighborhoods in the city of São Paulo (see Oliveira et al., 2019; 2020). 
for the second, both models successfully predicted the classes. I then fed the trained models with this study's data so as to classify the open-ended responses as either "consent", "coercive", "rejection of authority", or "disobedient protest." The final distribution across all three waves consists of $40 \%$ responses in the 'coercive' category, 33\% in the 'consent' category, 19\% in the 'rejection of authority' category, and $8 \%$ in the 'disobedient protest' category.

\section{[TABLE A2 ABOUT HERE]}

In order to estimate scores of police legitimacy at each time point, I would ideally use a wide dataset and fit a three-trait item response model with trait loadings of the same indicators over time constrained to equality to ensure measurement equivalence. However, such model was too computationally intense and never converged. As an alternative, I estimate a one-trait item response model using pooled data, which is preferrable than estimating three different models at each time point as it imposes measurement equivalence.

As per Jackson et al. (2022), the estimated construct is a bipolar continuum ranging from coercive to consensual motivations to comply with the law. Results of the item response model estimated by mPlus 7.11 using maximum likelihood with robust standard errors are displayed in Table A2. Respondents who are normatively aligned with the police will have higher scores $\left(\lambda_{1}=\right.$ 1.506), whereas respondents who perceive the police to be fearful will have lower scores $\left(\lambda_{2}=\right.$ $-0.601)$. Respondents who have a normatively grounded duty to obey the police and those who do not think they should obey as a form of a disobedient protest will also have scores shifted towards the legitimacy end of the continuum $\left(\lambda_{3}=0.511\right.$ and $\lambda_{4}=0.083$, respectively), whereas those who reject the police authority will have lower scores $\left(\lambda_{5}=-0.159\right)$ - in relation to the 'coercive obligation' category. Approximately normally distributed trait scores representing police legitimacy at each wave were then extracted and used in subsequent analyses.

\section{A.2 SCALING PROPERTIES AND EMPIRICAL DISTINCTIVENESS BETWEEN ALL LATENT CONSTRUCTS}

Table A3 displays all other survey items used in this study, tapping into the ideas of 'perceived police intrusion, 'cynicism about police protection', and 'perceived police procedural fairness'. All variables were measured in Portuguese and translated into English by me; both the original and the translated versions of all survey items are displayed.

\section{[TABLE A3 ABOUT HERE]}

Using only data from the first wave, I first estimate a number of confirmatory factor analysis models to assess the scaling properties of the three constructs and make sure they are empirically distinguishable, contrasting model fit statistics of models with different solutions. All models are 
estimated by R's package lavaan using diagonally weighted least squares (all indicators are set as ordinal). I fit five CFA models testing all possible combinations for three potential latent constructs: a one-factor solution where all indicators tap into a single construct; a two-factor model, where items tapping into both procedural fairness and police intrusion load onto a single construct, while items tapping into cynicism about police protection tap into another construct; another two-factor model, where items tapping into both police intrusion and cynicism about police protection load onto a single construct, whereas perceived procedural fairness is a separate construct; yet another two-factor model, in which items tapping into cynicism about police protection and perceived procedural fairness load onto a single construct, while perceived police intrusion is a separate latent variable; and, finally, a three-factor model in which perceived police intrusion, cynicism about police protection, and perceived procedural fairness are each distinct latent constructs.

\section{[TABLE A4 ABOUT HERE]}

Table A4 suggests that several combinations have an acceptable model fit, indicating that empirically distinguishing psychological constructs can be challenging. Yet, a three-factor solution clearly has the best model fit. The CFA model with three separate constructs has the highest scores of CFI (.999) and TLI (.997), the lowest score of RMSEA (.021), and is the only model that fails to reject the null hypothesis assuming that the observed covariance matrix is generated by the hypothesized model. While other combinations also have acceptable fit statistics - such as the two-factor solution collapsing perceived procedural fairness and cynicism about police protection - altogether, from a datadriven perspective these results demonstrate that the three constructs are indeed empirically distinguishable. In addition, from a theoretical point of view, considering all the reasons outlined in the rest of the paper, treating perceptions of procedural fairness and cynicism about police protection as two separate constructs is more appropriate. Given all these reasons combined, I treat all three latent constructs as three distinct, albeit correlated variables The three latent constructs are moderately to strongly correlated with each other, with the magnitude of all estimated correlation coefficients ranging from 0.47 to 0.59 .

\section{A.3 | MEASURING ALL LATENT CONSTRUCTS}

\section{[TABLE A5 ABOUT HERE]}

I then fit three separate pooled measurement models for polytomous data with logistic function links, each model measuring each latent construct of interest (i.e., perceptions of police intrusion, cynicism about police protection, and perceptions of procedural fairness), as explained in the paper. Empirical indicators (e.g., survey items) are regressed on an estimated latent variable, but with logistic function links as the indicators are categorical variables; in this case, function links are specified as ordinal logistic, as all indicators were measured based on Likert scales. Pooling data across all three 
waves ensures measurement equivalence as all trait loadings and intercepts are constrained to equality across waves, and therefore such model specifications can capture change over time in latent variables. Factor loadings for the three models are displayed in Table A5. I use trait scores derived from these models throughout the study.

[TABLES A6, A7, A8 ABOUT HERE]

Tables A6, A7 and A8 display correlation matrices between the three derived latent trait scores and scores of police legitimacy (the coercive-consensual continuum) at each time period. 
Table A1. Survey items used to measure the coercive-consensual continuum

\begin{tabular}{|c|c|}
\hline Survey items & Response alternatives \\
\hline $\begin{array}{l}\text { The police act in accordance with what you believe is right or wrong } \\
\text { (A polícia do seu bairro age de acordo com o que o(a) sr(a) acha que é certo) } \\
\text { People are afraid of the police } \\
\text { (As pessoas sentem medo da polícia) }\end{array}$ & $\begin{array}{l}\text { Never, rarely, sometimes, very often, always } \\
\text { (Nunca, raramente, às vezes, quase sempre, sempre) }\end{array}$ \\
\hline $\begin{array}{l}\text { Do you think you should obey the police even they believe they are wrong? } \\
(O(a) \operatorname{sr}(a) \text { acha que deve obedecer a polícia mesmo quando acredita que ela } \\
\text { está errada?) }\end{array}$ & $\begin{array}{l}\text { Yes, no } \\
(\text { Sim, não) }\end{array}$ \\
\hline $\begin{array}{l}\text { Why do you think you (should / should not) obey the police even when you } \\
\text { believe they are wrong? } \\
\text { (Por que você acredita que [deve / não deve] obedecer a polícia mesmo quando } \\
\text { ela está errada?) }\end{array}$ & $\begin{array}{l}\text { Normatively grounded duty to obey, coercive obligation to obey, } \\
\text { disobedient protest, rejection of authority (based on thematic } \\
\text { analysis and a text classification model) }\end{array}$ \\
\hline
\end{tabular}


Table A2. Item response model measuring police legitimacy using pooled data

\begin{tabular}{|c|c|c|c|}
\hline \multirow[b]{2}{*}{ Survey items } & \multicolumn{3}{|c|}{ Police legitimacy } \\
\hline & Est. & s.e. & Link function \\
\hline Act in accordance with what you believe & 1.506 & 0.328 & \multirow{2}{*}{ Ordinal logistic } \\
\hline People are afraid of the police & -0.601 & 0.101 & \\
\hline Normative duty to obey & 0.511 & 0.087 & \multirow{4}{*}{$\begin{array}{c}\text { Multinomial logistic } \\
\text { (reference: coercive } \\
\text { obligation) }\end{array}$} \\
\hline Disobedient protest & 0.083 & 0.113 & \\
\hline Rejection of authority & -0.159 & 0.093 & \\
\hline AIC & 24214.01 & & \\
\hline BIC & 24309.71 & & \\
\hline N. obs & 2926 & & \\
\hline
\end{tabular}


Table A3. Survey items and latent constructs

\begin{tabular}{|c|c|c|}
\hline Construct & Survey items & Response alternatives \\
\hline \multirow{3}{*}{$\begin{array}{l}\text { Cynicism about police } \\
\text { protection }\end{array}$} & $\begin{array}{l}\text { - How good a job are police in your neighborhood doing in relation to: keeping } \\
\text { the streets of my neighborhood peaceful (reverse coded) } \\
\text { (Como o(a) sr(a) avalia o trabalho da polícia no seu bairro em relação a: } \\
\text { manter as ruas do bairro tranquilas) }\end{array}$ & $\begin{array}{l}\text { Very bad, bad, neither good nor bad, good, } \\
\text { very good } \\
\text { (Muito ruim, ruim, nem bom nem ruim, bom }\end{array}$ \\
\hline & $\begin{array}{l}\text { - Police in my neighborhood ensure my safety (reverse coded) } \\
\text { (A polícia do seu bairro garante a sua segurança) }\end{array}$ & \multirow{8}{*}{$\begin{array}{l}\text { Never, rarely, sometimes, very often, } \\
\text { always } \\
\text { (Nunca, raramente, às vezes, quase sempre, } \\
\text { sempre) }\end{array}$} \\
\hline & $\begin{array}{l}\text { - Laws protect me (reverse coded) } \\
(O(a) \text { sr }(a) \text { sente que as leis o/a protegem?) }\end{array}$ & \\
\hline \multirow{2}{*}{$\begin{array}{l}\text { Perceptions of police } \\
\text { intrusion }\end{array}$} & $\begin{array}{l}\text { - Police officers act as if they were above the law in my neighborhood } \\
\text { (Os policiais no seu bairro agem como se estivessem acima da lei) }\end{array}$ & \\
\hline & $\begin{array}{l}\text { - Police officers follow and harass people in my neighborhood } \\
\text { (Os policiais no seu bairro perseguem e intimidam as pessoas) }\end{array}$ & \\
\hline \multirow{4}{*}{$\begin{array}{l}\text { Perceived procedural } \\
\text { fairness }\end{array}$} & $\begin{array}{l}\text { The police in your neighborhood: } \\
\text { (A polícia do seu bairro:) } \\
\text { - Explain clearly why they pull someone over } \\
\text { (Explica claramente por que revista ou prende as pessoas) }\end{array}$ & \\
\hline & $\begin{array}{l}\text { - } \quad \text { Make impartial and just decisions } \\
\text { (Toma decisões que são justas e imparciais) }\end{array}$ & \\
\hline & $\begin{array}{l}\text { - Pay attention to the information people provide them with } \\
\text { (Dá atenção às informações que as pessoas trazem) }\end{array}$ & \\
\hline & $\begin{array}{l}\text { - Treat people with respect } \\
\text { (Trata bem as pessoas) }\end{array}$ & \\
\hline
\end{tabular}


Table A4. Contrasting model fit statistics of five CFA models

\begin{tabular}{|c|c|c|c|c|c|}
\hline & One factor & Two factors & Two factors & Two factors & Three factors \\
\hline Latent constructs & $\begin{array}{l}\text { 1) Police Intrusion, } \\
\text { Cynicism about Police } \\
\text { Protection, and } \\
\text { Procedural Fairness } \\
\text { collapsed) }\end{array}$ & $\begin{array}{l}\text { 1) Cynicism about } \\
\text { Police Protection and } \\
\text { Procedural Fairness } \\
\text { collapsed; } \\
\text { 2) Police Intrusion. }\end{array}$ & $\begin{array}{l}\text { 1) Police Intrusion } \\
\text { and Procedural } \\
\text { Fairness collapsed; } \\
\text { 2) Cynicism about } \\
\text { Police Protection }\end{array}$ & $\begin{array}{l}\text { 1) Police Intrusion } \\
\text { and Cynicism about } \\
\text { Police Protection } \\
\text { collapsed; } \\
\text { 2) Procedural Fairness }\end{array}$ & $\begin{array}{l}\text { 1) Police Intrusion; } \\
\text { 2) Cynicism about } \\
\text { Police Protection; } \\
\text { 3) Procedural Fairness }\end{array}$ \\
\hline Estimation & $\begin{array}{l}\text { Diagonally weighted } \\
\text { least squares }\end{array}$ & $\begin{array}{c}\text { Diagonally weighted } \\
\text { least squares }\end{array}$ & $\begin{array}{c}\text { Diagonally weighted } \\
\text { least squares }\end{array}$ & $\begin{array}{l}\text { Diagonally weighted } \\
\text { least squares }\end{array}$ & $\begin{array}{c}\text { Diagonally weighted } \\
\text { least squares }\end{array}$ \\
\hline Chi-Square & 269.74 & 40.08 & 260.99 & 236.19 & 33.45 \\
\hline (degrees of freedom) & 27 & 26 & 26 & 26 & 24 \\
\hline $\mathrm{p}$-value & $\mathrm{p}<0.000$ & 0.038 & $\mathrm{p}<0.000$ & $\mathrm{p}<0.000$ & 0.095 \\
\hline CFI & 0.968 & 0.998 & 0.969 & 0.973 & 0.999 \\
\hline TLI & 0.958 & 0.997 & 0.957 & 0.954 & 0.998 \\
\hline RMSEA & 0.101 & 0.025 & 0.101 & 0.096 & 0.021 \\
\hline RMSEA CI & {$[0.090 ; 0.112]$} & [0.006; 0.039] & {$[0.090 ; 0.112]$} & {$[0.084 ; 0.107]$} & {$[0.000 ; 0.037]$} \\
\hline
\end{tabular}


Table A5. Three longitudinal models measuring latent constructs at three points in time

\begin{tabular}{lccc}
\hline & $\begin{array}{c}\text { Perceived police } \\
\text { intrusion }\end{array}$ & $\begin{array}{c}\text { Cynicism about } \\
\text { police protection }\end{array}$ & $\begin{array}{c}\text { Perceived } \\
\text { procedural fairness }\end{array}$ \\
\cline { 2 - 4 } & Loading & Loading & Loading \\
\hline Act as if above the law & 4.35 & & \\
Follow and harass people & 1.44 & & \\
Ensure my safety (rev.) & & 1.00 & \\
Keep the streets peaceful (rev.) & & 0.93 & \\
Laws protect me & & 0.68 & 1.00 \\
Explain clearly & & & 1.11 \\
Make impartial and just decisions & & & 1.18 \\
Pay attention to information & & & 1.09 \\
Treat people with respect & MLR & PML & PML \\
\hline Estimator & 2929 & 2929 & 2929 \\
N. obs & & & \\
\hline
\end{tabular}

Table A6. Correlation matrix between key constructs using first wave data

\begin{tabular}{ccccc}
\hline & $\begin{array}{c}\text { Perceived police } \\
\text { intrusion }\end{array}$ & $\begin{array}{c}\text { Cynicism } \\
\text { about police } \\
\text { protection }\end{array}$ & $\begin{array}{c}\text { Perceived } \\
\text { procedural } \\
\text { fairness }\end{array}$ & $\begin{array}{c}\text { Police } \\
\text { legitimacy }\end{array}$ \\
\hline Perceived police intrusion & 1 & & & \\
Cynicism about police protection & .24 & 1 & & \\
\hline Perceived procedural fairness & -.29 & -.57 & 1 & \\
Police legitimacy & -.31 & -.44 & .66 & 1 \\
\hline
\end{tabular}


Table A7. Correlation matrix between key constructs using second wave data

\begin{tabular}{ccccc}
\hline & $\begin{array}{c}\text { Perceived police } \\
\text { intrusion }\end{array}$ & $\begin{array}{c}\text { Cynicism } \\
\text { about police } \\
\text { protection }\end{array}$ & $\begin{array}{c}\text { Perceived } \\
\text { procedural } \\
\text { fairness }\end{array}$ & $\begin{array}{c}\text { Police } \\
\text { legitimacy }\end{array}$ \\
\hline Perceived police intrusion & 1 & & & \\
Cynicism about police protection & .20 & 1 & & \\
\hline Perceived procedural fairness & -.31 & -.57 & 1 & \\
Police legitimacy & -.32 & -.49 & .65 & 1 \\
\hline
\end{tabular}

Table A8. Correlation matrix between key constructs using third wave data

\begin{tabular}{ccccc}
\hline & $\begin{array}{c}\text { Perceived police } \\
\text { intrusion }\end{array}$ & $\begin{array}{c}\text { Cynicism } \\
\text { about police } \\
\text { protection }\end{array}$ & $\begin{array}{c}\text { Perceived } \\
\text { procedural } \\
\text { fairness }\end{array}$ & $\begin{array}{c}\text { Police } \\
\text { legitimacy }\end{array}$ \\
\hline Perceived police intrusion & 1 & & & \\
Cynicism about police protection & .30 & 1 & & \\
Perceived procedural fairness & -.37 & -.63 & 1 & \\
Police legitimacy & -.39 & -.53 & .64 & 1 \\
\hline
\end{tabular}




\section{REFERENCES}

Benoit, Kenneth, Kohei Watanabe, Haiyan Wang, Paul Nulty, Adam Obeng, Stefan Muller, and Akitaka Matsuo. 2018. "quanteda: An R Package for the Quantitative Analysis of Textual Data." The Journal of Open Source Software 3 (30): 774.

Hastie, Trevor, Robert Tibshirani, and Jerome Friedman. 2009. The Elements of Statistical Learning: Data Mining, Inference, and Prediction. Springer Science \& Business Media.

Jackson, Jonathan, Krisztián Pósch, Thiago R. Oliveira, Ben Bradford, Silvia M Mendes, Ariadne Lima Natal, and André Zanetic. Forthcoming, 2022. "Fear and Legitimacy in São Paulo, Brazil: Police-Citizen Relations in a High Violence, High Fear City." Law \& Society Review.

Oliveira, Thiago R., André R. Oliveira, and Sergio Adorno. 2019. "Legitimidade Policial: um Modelo de Mensuração." Revista Brasileira de Ciências Sociais 34 (100).

Oliveira, Thiago R., Andre Zanetic, and Ariadne Natal. 2020. "Preditores e Impactos da Legitimidade Policial: Testando a Teoria da Justeza Procedimental em São Paulo.” Dados - Revista de Ciências Sociais 63 (1). 